RECEIVEO

FEB 0 i 1938

OSTI

\title{
EBRII Cask Characterization Measurements
}
D. L. Haggard
L. W. Brackenbush

January 1996

Prepared for the U.S. Department of Energy under Contract DE-AC06-76RLO 1830

Pacific Northwest National Laboratory Operated for the U.S. Department of Energy by Battelle Memorial Institute 


\section{DISCLAIMER}

This report was prepared as an account of work sponsored by an agency of the United States Government. Neither the United States Government nor any agency thereof, nor-Battelle Memorial Institute, nor any of their employees, makes any warranty, express or implied, or assumes any legal liability or responsibility for the accuracy, completeness, or usefulnes's of any informaticn, apparatus, product, or process disclosed; or represents that its use would not infringe privately owned rights. Reference herein to ary specific commercial product, process, or service by trade name, trademark, mànufacturer, or otherwise does not necessarily constitute or împly, its endorsement, recommendation, or favoring by the United States Government or any agency-thereof, or Battelle Memorial Institute. The views and opinions of authors expressed herein do not necessarily state or reflect those of the United States Government or any agency thereof.

\section{PACIFIC NORTHWEST NATIONAL LABORATORY}

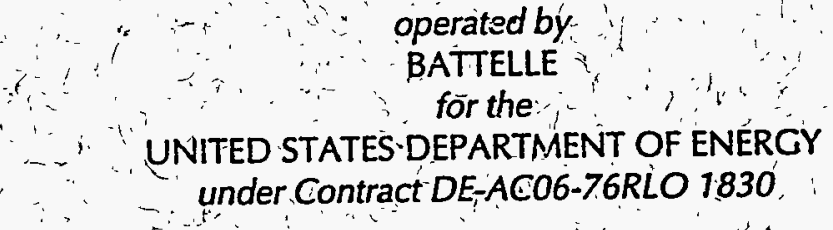

Printed in the United States of America

Available to DOE and DOE contractors from the

Office of Scientific and Technical Information, P.O. Box 62, Oak Ridge, TN 37831; pricés available from (615) 576-8401.

Available to the public from the National Technical Information Service, U.S. Department of Commerce, 5285 Port Royal Rd., Springfield, VA 22161 


\section{EBRII Cask Characterization Measurements}

D. L. Haggard

L. W. Brackenbush

January 1996

Prepared for

the U.S. Department of Energy

under Contract DE-AC06-76RLO 1830

Pacific Northwest National Laboratory

Richland, Washington 99352

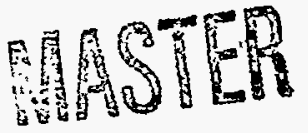





\section{Summary}

This report describes the measurements performed to provide the radionuclide content and verify the stated mass of special nuclear material (SNM) in Experimental Breeder Reactor EBRII casks stored in Trench 1, Burial Ground 4C, 218-WAC 200 West Area. This information is needed to characterize

the curie content of each cask and the total curies in the storage area. Gamma assay techniques typically employed for nondestructive assay (NDA) were used to determine the gamma-emitting isotopes in each cask, which were fission and activation products from the spent fuel. Passive neutron counting was selected to verify the stated plutonium content because the fission and activation products masked any gamma emissions from plutonium. The fast neutrons emitted by plutonium are highly penetrating and easily detected through several inches of shielding.

A slab neutron detector containing five ${ }^{3} \mathrm{He}$ proportional counters was used to determine the neutron emission rates and estimate the mass of plutonium present. The measurements followed the methods and procedures routinely used for nuclear waste assay and safeguards measurements. The measured neutron yields confirmed the deciared plutonium content for the fuel elements, with the exception of several casks that contained recycled plutonium or americium target material. In these casks, the ${ }^{244} \mathrm{Cm}$ content masked the neutron emissions from any plutonium. For these casks, the plutonium content was estimated by correlation with the ${ }^{244} \mathrm{Cm}$ neutron emissions.

The fission product inventories in the casks were estimated using gamma ray NDA techniques. An intrinsic germanium detector was used to measure the characteristic gamma ray spectra of the fission and activation products in each cask. From the gamma ray intensities measured and the decay scheme of specific radionuclides, it is possible to obtain reasonably accurate estimates of the amount of specific gamma-emitting nuclides. The majority of the nontransuranic activity present originates from fission products ${ }^{137} \mathrm{Cs},{ }^{154} \mathrm{Eu}$, and ${ }^{134} \mathrm{Cs}$ and the activation product ${ }^{60} \mathrm{Co}$. Plutonium and uranium quantities are based on shippers' values from DOE-741 forms. The stated transuranic values were verified by these measurements. Nontransuranic curie content for each cask is presented based on ISOGEN burn-up data and ${ }^{137} \mathrm{Cs}$ curie correlation. 



\section{Acknowledgments}

The WHC crane operators, HPTs, riggers, and other ground-support operations personnel are to be commended for their exemplary professionalism and work ethic shown on this job. They performed the duties of moving, staging, and restaging the EBRII casks in a safe and expeditious manner. Thanks also to Don Pyzel who was the person in charge for all aspects of the EBRII cask characterizations. He conducted the pre-job meetings, arranged for support personnel, and made everything work smoothly. Thanks to Dean Pratt, cognizant engineer, and Carla Thibault for preparing the work plan; Bernie Poremba and Dean Puryear for providing historical data on the casks and contents.

Acknowledgment of the support from the following PNL personnel is in order: comments and historical data from Bob Spinks, Del DesChane, and Glenda Ackerman; management direction from Jim Seay, Don Knowlton and Wayne Slater; measurement support provided by coworker Cecelia Lemons. 



\section{Acronyms}

MCA multichannel analyzer

NBS National Bureau of Standards

NDA nondestructive assay

NIST National Institute of Standards and Technology

PNL Pacific Northwest Laboratory

QA quality assurance

RIDS Records Inventory and Disposition Schedule

SNM special nuclear materials

WHC - Westinghouse Hanford Company 



\section{Contents}

Summary $\ldots \ldots \ldots \ldots \ldots \ldots \ldots \ldots \ldots \ldots \ldots \ldots \ldots \ldots \ldots \ldots \ldots$ iii

Acknowledgments $\ldots \ldots \ldots \ldots \ldots \ldots \ldots \ldots \ldots \ldots \ldots \ldots \ldots \ldots \ldots$

Acronyms $\ldots \ldots \ldots \ldots \ldots \ldots \ldots \ldots \ldots \ldots \ldots \ldots \ldots \ldots \ldots \ldots \ldots$ vii



1.1 Gamma Assay $\ldots \ldots \ldots \ldots \ldots \ldots \ldots \ldots \ldots \ldots \ldots \ldots \ldots \ldots \ldots \ldots$

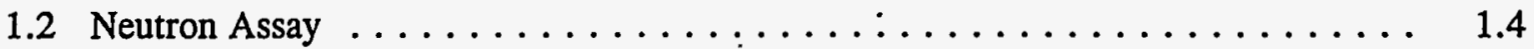

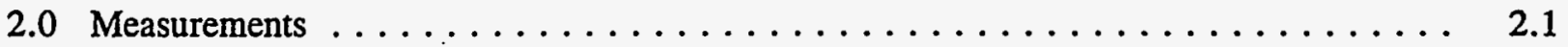

2.1 Measurement and Test Equipment $\ldots \ldots \ldots \ldots \ldots \ldots \ldots \ldots \ldots \ldots \ldots \ldots \ldots$

2.2 Calibration Standards $\ldots \ldots \ldots \ldots \ldots \ldots \ldots \ldots \ldots \ldots \ldots \ldots \ldots \ldots \ldots$

2.3 Measurement and Quality Control $\ldots \ldots \ldots \ldots \ldots \ldots \ldots \ldots \ldots \ldots \ldots \ldots$

2.3.1 Preparations for Measurement and Test Equipment Used . . . . . . . . . 2.2

2.3.2 Neutron Slab Detector System $\ldots \ldots \ldots \ldots \ldots \ldots \ldots \ldots \ldots \ldots \ldots$

2.4 Pretest Verifications $\ldots \ldots \ldots \ldots \ldots \ldots \ldots \ldots \ldots \ldots \ldots \ldots \ldots \ldots \ldots \ldots$

2.4.1 Testing of Electronics $\ldots \ldots \ldots \ldots \ldots \ldots \ldots \ldots \ldots \ldots \ldots \ldots$

2.4.2 Angular Response Measurements . . . . . . . . . . . . . 2.3

2.4.3 Calibration of Slab Detector with Plutonium Oxide $\ldots \ldots \ldots \ldots \ldots$

2.5 Neutron Measurements in 200 West Area $\ldots \ldots \ldots \ldots \ldots \ldots \ldots \ldots \ldots$

2.5 .1 Operational Check $\ldots \ldots \ldots \ldots \ldots \ldots \ldots \ldots \ldots \ldots \ldots \ldots \ldots$

2.5.2 Background Measurements $\ldots \ldots \ldots \ldots \ldots \ldots \ldots \ldots \ldots \ldots \ldots$

2.5.3 Measurement Scenario $\ldots \ldots \ldots \ldots \ldots \ldots \ldots \ldots \ldots \ldots \ldots$ 


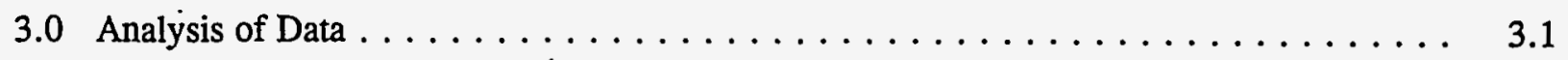

3.1 Results of Neutron Measurements . . . . . . . . . . . . . . 3.4

3.2 Results from Gamma Spectral Data . . . . . . . . . . . . . 3.6

3.3 Measurements of $2736-\mathrm{ZD}$ Vault $\ldots \ldots \ldots \ldots \ldots \ldots \ldots \ldots \ldots \ldots \ldots \ldots$

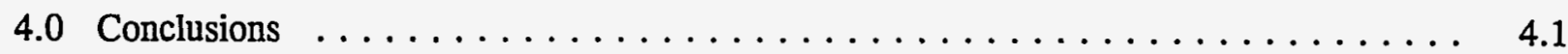

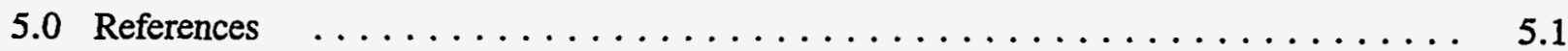




\section{Figures}

2.1 Pulse Height Distribution from the ${ }^{3} \mathrm{He}$ Proportional Counter . . . . . . . . . . . 2.4

2.2 Angular Response of the 6-inch Thick Slab Neutron Detector to Fission Neutrons . . . . 2.5

3.1 Verification of ${ }^{240} \mathrm{Pu}$ Content from Neutron Yield Measurements on EBRII Casks $\ldots \ldots \quad 3.4$

3.2 Correlation of ${ }^{244} \mathrm{Cm}$ Content from Neutron Counting with Burn-up Estimated by ${ }^{137} \mathrm{Cs}$ Content per Gram of Fuel $\ldots \ldots \ldots \ldots \ldots \ldots \ldots \ldots \ldots \ldots \ldots$

3.3 Curium-244 Content in Recycled Plutonium Fuels Estimated from Neutron Yield

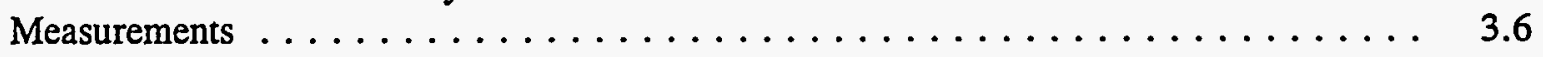

3.4 Gamma Spectrum of LAMPRE MOX Fuel Cask $\ldots \ldots \ldots \ldots \ldots \ldots \ldots \ldots$

3.5 Gamma Spectrum of Recycled MOX Fuel $\ldots \ldots \ldots \ldots \ldots \ldots \ldots \ldots \ldots$

3.6 Gamma Spectrum of MOX Carbide Fuel Cask $\ldots \ldots \ldots \ldots \ldots$

3.7 Gamma Spectrum of Irradiated ${ }^{241}$ Am Target Cask $\ldots \ldots \ldots \ldots \ldots \ldots$

3.8 Gamma Spectrum of Leached Spent Fuels Hulls Cask $\quad \ldots \ldots \ldots \ldots \ldots$

3.9 Neutron Intensity Measured Around the Circumference of the 2736-ZD Cylindrical Storage Vault Using the Slab Neutron Detector . . . . . . . . . . . . . 3.10

3.10 Cross-sectional View of 2736-ZD Storage Vault Showing the Position of Three EBRII Spent Fuel Casks Estimated from Neutron Counting $\ldots \ldots \ldots \ldots \ldots \ldots$

3.11 Angular Response of the Collimated Fast Neutron Detector Measured Using a

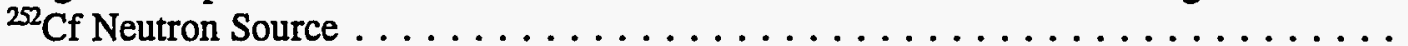

3.12 Measurement of Three EBRII Casks Located Inside the 2736-ZD Concrete Storage Vault Measured Using the Collimated Fast Neutron Detector Positioned at the Southeast Side 


\section{Tables}

1.1 Basic Nondestructive Assay Procedure NDA-510 $\ldots \ldots \ldots \ldots \ldots \ldots \ldots \ldots$

2.1 Isotopic Composition of Plutonium Ash Reference Material, Weight Percent Isotope $\ldots \quad 2.2$

2.2 Effect of Steel and Aluminum Shielding Materials Placed Between the Plutonium and

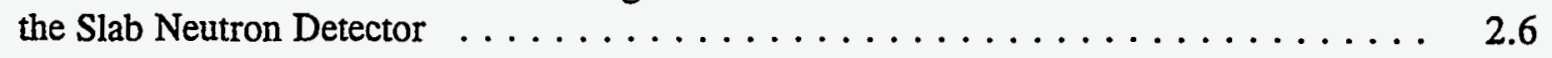

3.1 Neutron and Gamma Measurement Results $\ldots \ldots \ldots \ldots \ldots \ldots \ldots \ldots \ldots$

3.2 Nontransuranic Curie Content from Gamma Measurements . . . . . . . . . . 3.2

3.3 Nontransuranic Curies Based on ${ }^{137} \mathrm{Cs}$ Burn-up Estimates and ISOGEN Calculations . . . $\quad 3.3$ 


\subsection{Introduction}

This report describes measurements performed by staff at the Pacific Northwest Laboratory (PNL) to determine the radionuclide content and verify the mass of special nuclear material (SNM) stored in casks buried on the Hanford Site. The casks contain spent nuclear fuel. This information is needed to characterize the curie content of each cask and the total curies in the storage area.

The Experimental Breeder Reactor (EBRII) casks are situated on an asphalt pad in two rows in Trench 1, Burial Ground 4C in the 218-WAC-200 West Area of the Hanford Site. The casks are spaced with $1.5-\mathrm{m}(5-\mathrm{ft})$ centers to ensure criticality safety and to facilitate access.

Gamma assay techniques typically used for nondestructive assay (NDA) determined the gammaemitting isotopes in each cask, which are fission and activation products from the spent fuel. An intrinsic germanium detector was used to measure the gamma ray spectra of the fission and activation products. From the gamma ray intensities measured and the decay scheme of specific radionuclides, it is possible to obtain reasonably accurate estimates of the amount of specific gamma-emitting radionuclides. The majority of the nontransuranic activity originates from fission products ${ }^{137} \mathrm{Cs},{ }^{154} \mathrm{Eu}$, and ${ }^{134} \mathrm{Cs}$ and from the activation product ${ }^{60} \mathrm{Co}$.

Following a brief explanation of the gamma and neutron measurement techniques used, this report discusses the process of measuring the radionuclide content of the casks (Section 2.0) and reports on the analysis of the data (Section 3.0).

To verify that the plutonium content was as assumed, passive neutron counting was also done because ${ }^{244} \mathrm{Cm}$ masked gamma emissions from the plutonium. The plutonium content was estimated by correlation with the ${ }^{244} \mathrm{Cm}$ neutron emissions. Fast neutrons from plutonium are highly penetrating and can be easily detected through several inches of shielding. A slab neutron detector containing five ${ }^{3} \mathrm{He}$ proportional counters was used to determine the neutron emission rates and estimate the mass of plutonium present. The measurements followed the methods and procedures routinely used for nuclear waste assay and safeguards measurements.

\subsection{Gamma Assay}

Gamma assay has an advantage over neutron assay in that the emissions are primarily from the principle isotopes of interest. High-purity intrinsic germanium (HPIG) detectors provide very high resolution for the individual gamma rays and allow separation of mixed isotopes gamma energy lines. The HPIGs are available with different relative efficiencies. Gamma.energy analysis includes the following considerations: 
- collimator (gamma) - shape and size

- sample - shape and size

- distance from sample to detector

- shielding, absorption, scattering within the matrix of sample

- background interferences

- filters for detector

- detector efficiency and size

- angular response of the detector/collimator.

The gamma assay procedures used for the EBRII casks followed the methodology set forth in PNL Non-Destructive Assay Procedure MCA-510. This procedure is summarized in Table 1.1.

Attenuation corrections are necessary when a point-line-area calibration has been performed without correction for container absorption during the initial calibration. The measured response must be corrected using the following formula:

$$
C_{\text {corr }}=C_{\text {meas }} e^{\mu \rho x}
$$

$$
\text { where } \begin{aligned}
\mathrm{C}_{\text {corr }} & =\text { corrected response }(\mathrm{cts} / \mathrm{s}) \\
\mathrm{C}_{\text {meas }} & =\text { measured response }(\mathrm{cts} / \mathrm{s}) \\
\mu & =\text { mass-attenuation coefficient }\left(\mathrm{cm}^{2} / \mathrm{g}\right) \\
. \rho & =\text { density of the container material }\left(\mathrm{g} / \mathrm{cm}^{3}\right) \\
\mathrm{x} & =\text { thickness of the material }(\mathrm{cm}) .
\end{aligned}
$$

Sample self-attenuation corrections can be estimated by initially computing the quantity as if there were no self-attenuation and later correcting once the thickness can be estimated. The equation for the self-attenuated correction factor $\left(\mathrm{CF}_{\mathrm{sa}}\right)$ is as follows:

$$
\begin{aligned}
& \mathrm{CF}_{\mathrm{sa}}=\frac{\mu \rho \chi}{1-\mathrm{e}^{-\mu \rho \chi} .} \\
& \mathrm{m}_{\text {cos }}=\mathrm{m} \times \mathrm{CF}_{\mathrm{sa}}
\end{aligned}
$$

where $\mathrm{m}_{\text {corr }}=$ corrected SNM (g). 
Table 1.1. Basic Nondestructive Assay Procedure MCA-510

\begin{tabular}{|c|c|}
\hline Step 1 & Set up the assay system components in the laboratory and perform pretest verifications. \\
\hline Step 2 . & $\begin{array}{l}\text { Perform energy calibration and measurement control procedure, completing Exhibit A of } \\
\text { NDA Assay Procedure MCA-510. }\end{array}$ \\
\hline Step 3 & $\begin{array}{l}\text { Perform calibrations for the assay scenario. In this case a collimated HPGe detector was } \\
\text { positioned at a known distance from small calibrated gamma sources. }\end{array}$ \\
\hline Step 4 & $\begin{array}{l}\text { Move instrumentation to location and verify no damage has occurred. Perform an energy } \\
\text { calibration and measurement control procedure, completing Exhibit A of NDA Assay } \\
\text { Procedure MCA-510. }\end{array}$ \\
\hline Step 5 & $\begin{array}{l}\text { Determine ambient background(s) at the counting location and evaluate counting techniques } \\
\text { to assure that the background will not compromise the measurement. }\end{array}$ \\
\hline Step 6 & $\begin{array}{l}\text { Perform measurements with intermittent control checks, record data and location, and } \\
\text { assign NDA Log numbers using Exhibit B of NDA NonDestructive Assay Measurement } \\
\text { Procedure MCA- } 510 \text {. }\end{array}$ \\
\hline Step 7 & $\begin{array}{l}\text { Transfer data and analyze using software acquisition and analyses codes, and computer } \\
\text { spreadsheets. Retain the original data for archive, logging the file name on the Exhibit B, } \\
\text { PNL NDA Analysis Log/Report. }\end{array}$ \\
\hline Step 8 & $\begin{array}{l}\text { Evaluate the data results and determine the appropriate correction factors, including the } \\
\text { detector filters. Initial basic assumptions are made of the source material, one being that } \\
\text { the sample self-attenuation is negligible. Actual attenuation correction factors can be } \\
\text { applied after measurements are made and more reasonable assumptions are determined as to } \\
\text { the material matrix and configuration. All counts measured are corrected by the attenuation } \\
\text { correction factors (CF). Generally, a density value in grams per cubic centimeter (g/cc) is } \\
\text { derived for the item based on gross weight of the container minus the container weight } \\
\text { and/or shielding and/or packaging materials. This matrix density value is used for the } \\
\text { attenuation corrections for the gamma energies measured. }\end{array}$ \\
\hline Step 9 & a Ief \\
\hline
\end{tabular}

The thickness of the material can be estimated from the container volume and the density of the deposit:

$$
\mathrm{m}=\mathrm{K}_{\mathrm{p}} \times \mathrm{C}_{\mathrm{corr}} \times \mathrm{r}^{2}
$$

where $\mathrm{K}_{\mathrm{p}}$ is the calibration constant for point source $\left(\mathrm{g} \cdot \mathrm{s} / \mathrm{cts} \cdot \mathrm{cm}{ }^{2}\right)$ and $\mathrm{r}$ is the distance between the detector and the center of measured item $(\mathrm{cm})$. 
Area source measurements calculations are computed as follows:

$$
\mathrm{m}=\mathrm{K}_{\mathrm{a}} \times \mathrm{C}_{\text {corr }} \times \mathrm{a}
$$

where $\mathrm{K}_{\mathrm{a}}$ is the area-source calibration constant $\left(\mathrm{g} \cdot \mathrm{s} / \mathrm{cts} \cdot \mathrm{cm}^{2}\right)$ and a is the measured area $\left(\mathrm{cm}^{2}\right)$.

Attenuation corrections can be determined by calculation or transmission measurements. Although in practice this correction is merely an estimate, it is important to make this correction for every holdup measurement. Miscalculation or neglecting of self-absorption and attenuation corrections can result in an underestimation of the material in holdup.

The data report package includes the NDA Log numbers for the items assayed as a reference to the measurement data files from which the analysis was derived. The NDA Log numbers are maintained as Project Files by the PNL NDA Program. Additional documentation is described in the report or the test plan associated with the assay. Measurement data files, or raw data files, are maintained according to the Records Inventory and Disposition Schedule (RIDS) for the PNL NDA Program, applicable waste acceptance criteria, and regulatory criteria.

\subsection{Neutron Assay}

Passive neutron counting is a recognized technique for nondestructive assay of plutonium and is described in Chapter 14, "Principles of Neutron Counting" in the book, Passive Nondestructive Assay of Nuclear Materials, NUREG/CR-5550 (Reilly et al. 1991). Neutrons emitted by plutonium originate from two main sources: 1) spontaneous fission of even-numbered plutonium isotopes and 2) alphaneutron reactions with any low-atomic-number materials in intimate contact with the plutonium. Most of the neutrons originate from ${ }^{238} \mathrm{Pu},{ }^{240} \mathrm{Pu}$, and ${ }^{241} \mathrm{Am}$, which is the decay product of the short-lived nuclide ${ }^{2 A 1} \mathrm{Pu}$. Thus, it is important to know not only the isotopic composition of the plutonium, but also the time since chemical separation or the ${ }^{241} \mathrm{Am}$ content to be able to estimate the neutron contribution from ${ }^{241} \mathrm{Am}$. In many practical situations, the number of neutrons produced by alphaneutron reactions can exceed the spontaneous fission production from plutonium. Alpha-neutron reactions in compounds, such as plutonium oxide, can double the number of neutrons emitted. But any alpha-emitter in contact with low-atomic-number nuclides will produce neutrons. For example, transuranics that are in intimate contact with beryllium, boron, aluminum, or sodium will produce neutrons. The neutron emission rates from alpha-neutron reactions can be tens to hundreds of times higher than from pure plutonium metal.

In the case of extremely high burn-up material or americium targets, neutron emission rates from ${ }^{244} \mathrm{Cm}$ can be higher than those from plutonium. In these cases, the plutonium content must be inferred by correlation using historical data to relate plutonium content with ${ }^{244} \mathrm{Cm}$ content or neutron emission rates.

The methods used to measure the neutron emission rates from plutonium are virtually identical to those presented previously in the section on gamma assay, including the use of the same forms to 
record data. The details of the procedures need not be repeated here. However, because neutrons readily scatter from earth and concrete, some additional measurements are necessary to correct for the effects of scatter. These methods are outlined in the National Bureau of Standards (NBS) Special Publication 633 (Schwartz and Eisenhauer 1982) using procedures that were originally developed at. PNL for neutron flux measurements. 



\subsection{Measurements}

The measurements were conducted according to the following documents:

- Solid Waste Operations Work Plan, SW-WP-0078

- Quality Assurance (QA) Plan QAP FO-1, QA plan for the Safeguards NDA

- PNL Nondestructive Assay Measurement Procedure MCA-510, Holdup Assay Measurements.

\subsection{Measurement and Test Equipment}

The neutron assay system is a "user to calibrate" system. The individual components are configured and tested as a system, and then the entire system is calibrated with appropriate calibration/verification standards. The gamma assay system is calibrated with gamma check sources with calibrations traceable to the National Institute of Standards and Technology (NIST).

\subsection{Calibration Standards}

Calibration standards are used in a measurement system to establish the relationship between the basic instrument response and the attributes of interest. The quality of the calibration is ensured by selecting the appropriate standard. In this case, the count rate from neutrons, the amount of shielding, and the orientation and distance from the detector to the neutron source are related to the mass of plutonium. The calibration of the gamma assay equipment is more straightforward. The counting efficiency of the gamma spectrometer is measured using calibration sources of known activity and photon emission rates.

Records indicate that the material in the casks was from a wide variety of sources, including both low-exposure and high-exposure reactor fuel samples. Two neutron sources were selected for use in calibrating/verifying the neutron detector assay system. The first was a small $0.3-\mu \mathrm{g}{ }^{252} \mathrm{Cf}$ neutron calibration source whose neutron dose rates have been determined by comparison with other neutron sources whose calibrations are directly traceable to the NIST. This source has a neutron energy spectrum very similar to that of plutonium dioxide. ${ }^{(a)}$ This source was used to determine the angular efficiency of the slab detector in the laboratory prior to the measurements at 200 West.

A sample of weapons grade plutonium oxide was selected as the reference material standard for determining the basic instrument response for the attributes of interest. The isotopic composition of this reference source is shown in Table 2.1.

(a) See ${ }^{252}$ Cf Shielding Guide, DP-1246 (Stoddard and Hootman 1971) or NBS Special Publication 633 (Schwartz and Eisenhauer 1982). 
Table 2.1. Isotopic Composition of Plutonium Ash Reference Material, Weight Percent Isotope ${ }^{(a)}$

\begin{tabular}{||c|c|c|c|c|c||}
\hline${ }^{238} \mathrm{Pu}$ & ${ }^{239} \mathrm{Pu}$ & ${ }^{240} \mathrm{Pu}$ & ${ }^{241} \mathrm{Pu}$ & \multicolumn{1}{|c|}{${ }^{242} \mathrm{Pu}$} & ${ }^{241} \mathrm{Am}$ \\
\hline 0.13825 & 93.452 & 6.101 & 0.2793 & 0.019 & 0.220 \\
\hline $\pm 1.53 \%$ & $\pm 0.15 \%$ & $\pm 2.21 \%$ & $\pm 1.22 \%$ & $\mathrm{n} / \mathrm{a}$ & $\pm 1.4 \%$ \\
\hline (a) Calculated age from ratio of ${ }^{241} \mathrm{Am} /{ }^{241} \mathrm{Pu}$ is $12.3 \pm 0.33$ years. \\
\hline
\end{tabular}

\subsection{Measurement and Quality Control}

The measurement personnel had the complete responsibility for monitoring and evaluating the quality of the data. Any indication that the system is out-of-control (i.e., significant gain shifts in the position of the thermal neutron peak or high gamma levels that produce pile-up in the neutron events) required the stoppage of work until the problem was resolved. Before NDA measurements were initiated, the overall system was calibrated. To verify the proper operation of the neutron assay system, the entire system was assembled in the laboratory and components checked for proper operation. All of the spectral data collected during the measurements were recorded on computer files and can be retrieved if questions should arise.

A verification check was performed before the equipment was used, and the results recorded. The verification check was used to check the position of the thermal neutron peak and verify that the integral of the neutron events remained constant throughout the measurements. For the gamma assay system, the germanium detector was exposed to a calibration source containing a known activity of radioactive material. An analysis of photopeak areas and channel number was used to verify that the energy and detector efficiency remained constant.

\subsubsection{Preparations for Measurement and Test Equipment Used}

A slab neutron detector was selected for the measurements because of its sensitivity and directionality. With additional polyethylene on the backside of the detector, it is less sensitive to scattered neutrons emanating from the other spent fuel casks.

\subsubsection{Neutron Slab Detector System}

The neutron detector system consists of:

- a slab neutron detector containing five ${ }^{3} \mathrm{He}$ proportional counters inside a polyethylene moderator

- ancillary NIM bin electronics (preamplifier, shaping amplifier, high voltage power supply)

$\therefore$ a multichannel analyzer (MCA) to display and record the gamma and neutron spectra from the detectors. 
The slab neutron detector consists of an array of five cylindrical ${ }^{3} \mathrm{He}$ proportional counters that are $2.5 \mathrm{~cm}$ (1 in.) in diameter by approximately $56 \mathrm{~cm} \mathrm{(22} \mathrm{in.)} \mathrm{long,} \mathrm{filled} \mathrm{with} \mathrm{four} \mathrm{atmospheres} \mathrm{of}{ }^{3} \mathrm{He}$ to detect slow neutrons. The nominal operating voltage is +1400 volts. The polyethylene moderator is $15 \mathrm{~cm}$ (6 in.) deep, $41 \mathrm{~cm}$ (16 in.) wide, and $60 \mathrm{~cm}$ ( 24 in.) long. The detector is a standard design used for NDA safeguards assay and is described in Section 14.4.2 of NUREG/CR-5550, Passive Nondestructive Assay of Nuclear Materials (Reilly et al. 1991).

The NIM bin electronics include a high-voltage power supply to provide a regulated voltage of +1400 volts $\mathrm{DC}$ to operate the proportional counters and a shaping amplifier to convert the signals from the preamplifier to pulses that can be processed by the MCA. A multichannel analyzer was used to record the spectra, so that any possible gamma interference or instrument malfunction could be detected immediately. Data from the MCA (Canberra Series 35 Plus) are recorded in a lap top computer with a hard disk for permanent data storage. If there is any question about a measurement, the spectral data can be retrieved and examined at a later time.

\subsection{Pretest Verifications}

Before the equipment was used in the field, it was tested to ensure proper operation. This was accomplished by a testing in the laboratory under carefully controlled conditions. The equipment was then moved to the measurement locations and a second verification test performed to ensure that the equipment was still functioning properly.

\subsubsection{Testing of Electronics}

The neutron slab detector and high-purity germanium detector along with supporting electronics were assembled in the laboratory and all of the electronic components were checked to ensure proper operation in the field. The electronics were placed in the NIM bin and the cables connected for the signals, high voltage, and preamplifier power. The methods used to verify the proper operation of the equipment in the laboratory generally followed the methodology given in NUREG/CR-3610 (Brackenbush et al. 1984) and measurement procedures in NDA-510.

Figure 2.1 shows the pulse height spectrum from the slab neutron detector. The sharp peak corresponds to the events produced by the absorption of thermal neutrons in the ${ }^{3} \mathrm{He}$ tubes; it demonstrates that all of the ${ }^{3} \mathrm{He}$ tubes have matched gains and are functioning properly. Photons produce low-energy depositions and can be readily discriminated on the basis of pulse height. In Figure 2.1, the discrimination between neutron-induced and photon-induced events is indicated by the arrow indicating the "start of neutron events."

\subsubsection{Angular Response Measurements}

The first set of calibration/verification measurements was made in the ESB Building laboratory using the $0.3 \mu \mathrm{g}{ }^{252} \mathrm{Cf}$ neutron source to set up the system electronics and determine the angular response of the slab detector. The angular response of the 15-cm (6-in.) slab neutron detector exposed to the ${ }^{252} \mathrm{Cf}$ fission 


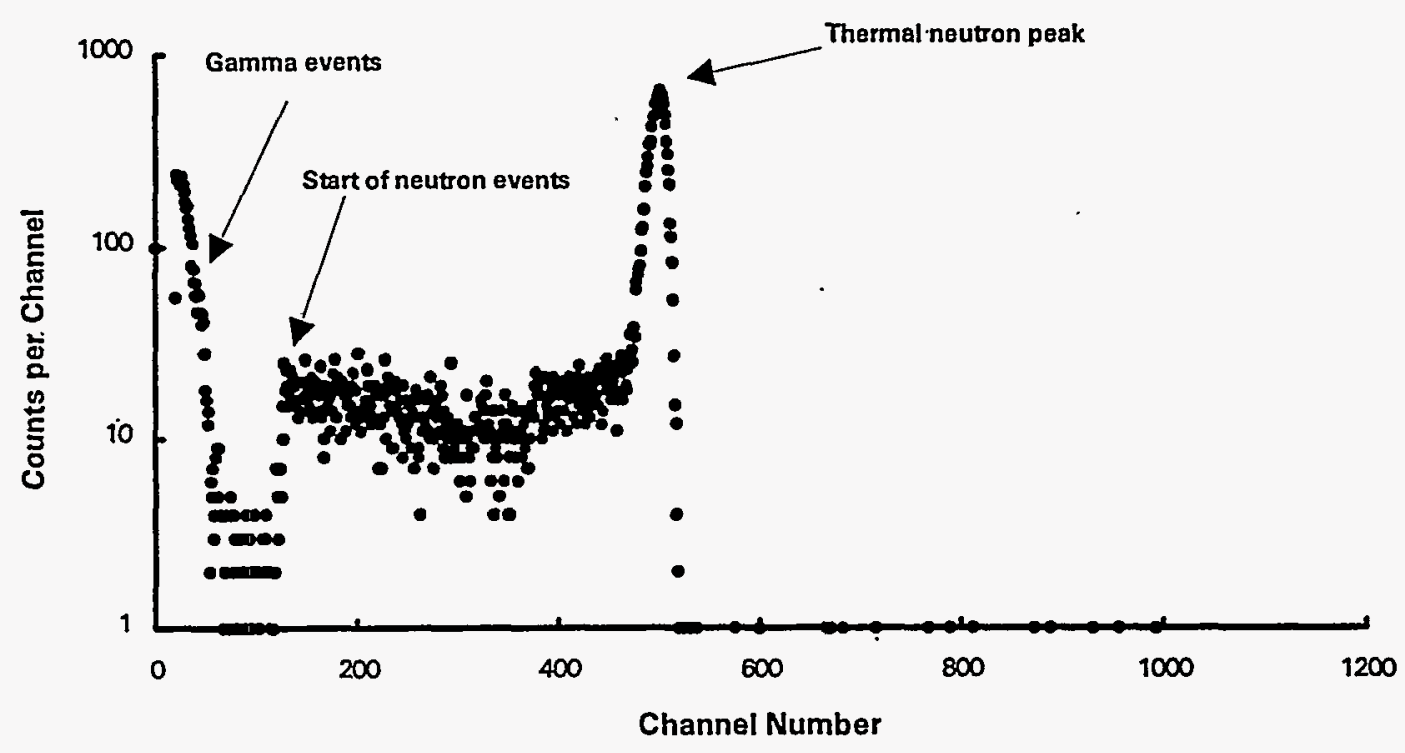

Figure 2.1. Pulse Height Distribution from the ${ }^{3} \mathrm{He}$ Proportional Counter

source is shown in Figure 2.2. Angles are measured in reference to an axis normal to the center of the front face of the slab detector. The front face has the five ${ }^{3} \mathrm{He}$ tubes located at $5 \mathrm{~cm}(2 \mathrm{in}$.) below the surface of the plastic moderator. The azimuthal angles are measured in the plane passing through the longest axis of the rectangular slab; polar angles are measured in a plane at right angles to the longest axis of the rectangular slab. These measurements were made in the ESB Laboratory at a height of 1.2 $\mathrm{m}(4 \mathrm{ft}$ ) above the floor. The angular responses were.measured with the slab detector positioned vertically on a turntable; the neutron source was at a distance of $2 . \mathrm{m}(6 \mathrm{ft})$ from the center of the ${ }^{3} \mathrm{He}$ tubes. The angular response measurements demonstrated that the response was reasonably constant for neutrons entering from the front, so that small errors in positioning would have little effect on the measurements. Also, the response for neutrons entering the back. was about half of that for neutrons entering from the front. This reduces the interference from background neutrons.

\subsubsection{Calibration of Slab Detector with Plutonium Oxide}

The slab detector was also calibrated in the 324 Building by exposing the detector to a 108-g

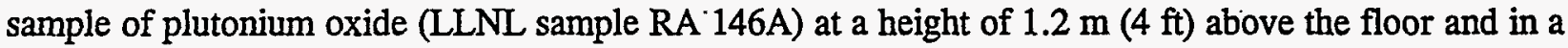
vertical configuration. The 108-g plutonium source has been described previously in Section 2.2. The data in Table 2.2 were used to correct neutron response due to matrix effects of the EBRII casks.

\subsection{Neutron Measurements in 200 West Area}

This section describes the neutron and photon measurements performed on the casks, which were stored in the 200 West Area. This included operational checks, background measurements, as well as the actual cask measurements. 


\section{Slab Detector Response for Polar Angles}

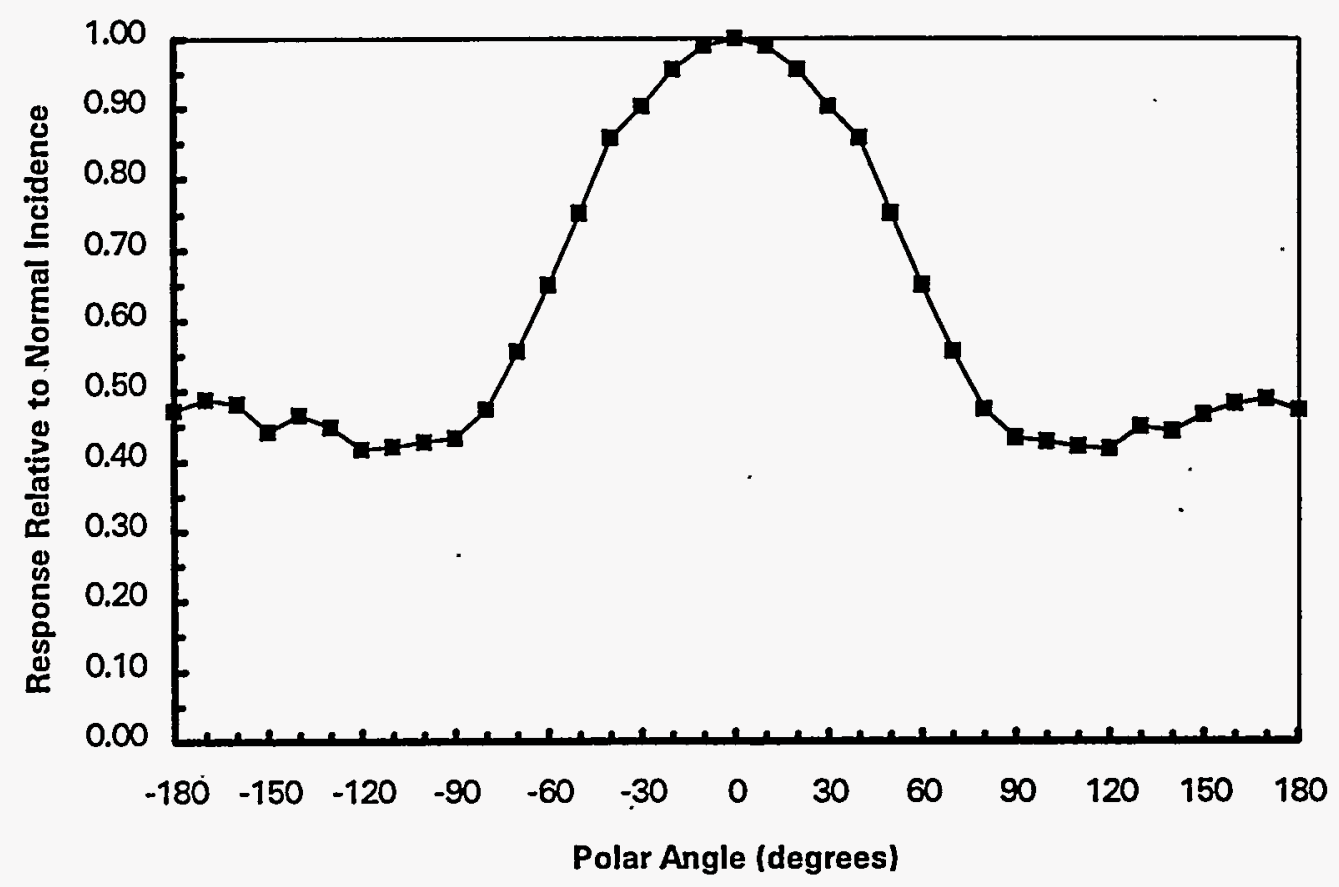

Figure 2.2. Angular Response of the 6-inch Thick Slab Neutron Detector to Fission Neutrons

\subsubsection{Operational Check}

After the preliminary measurements were completed in the laboratory and the system was functioning properly, it was moved to the 200 West Area. Here, the neutron detector was connected to the MCA via $30-\mathrm{m}$ (100-ft) cables, so that the operator could remain in low-dose-rate areas while the detector was positioned near the cask. After the operational check indicated that the system was still functioning properly, it was ready for neutron measurements on the casks.

\subsubsection{Background Measurements}

Any other neutron sources could contribute significantly to the neutron count rate, so careful background measurements were made before any measurements were made on the casks. The detector was designed to have a directional response, so that fission neutrons entering from the back would be counted with only half of the efficiency of those entering from the front of the slab detector. The slab detector was positioned in a vertical orientation to measure the general background. 
Table 2.2. Effect of Steel and Aluminum Shielding Materials Placed Between the Plutonium and the Slab Neutron Detector

\begin{tabular}{|l|r|c|c|}
\hline & \multicolumn{2}{|c|}{ Thickness } & \\
\hline Material & cm & inches & Attenuation Factor \\
\hline Steel & None & None & 1.00 \\
\hline & 2.5 & 1 & 0.85 \\
\hline & 5.1 & 2 & 0.75 \\
\hline & 7.6 & 3 & 0.68 \\
\hline & 10.2 & 4 & 0.60 \\
\hline & 15.2 & 6 & 0.49 \\
\hline Aluminum & None & None & 1.00 \\
\hline & 1.3 & 0.5 & 0.94 \\
\hline & 3.8 & 1.5 & 0.84 \\
\hline & 5.1 & 2.0 & 0.80 \\
\hline & 8.9 & 3.5 & 0.68 \\
\hline & 10.2 & 4.0 & 0.65 \\
\hline
\end{tabular}

\subsubsection{Measurement Scenario}

The nondestructive assay of the 36 casks stored in the trench was performed on swing shifts on September 22 and 27, 1994. A neutron slab detector was used to count passive neutrons from spontaneous fission and alpha-neutron reactions. A shielded high-purity germanium detector was used to measure gamma-emitting radionuclides from each cask.

The casks are situated on an asphalt pad in two rows with each cask spaced on $1.5 \mathrm{~m}(5 \mathrm{ft})$ centers. This arrangement provides the necessary spacing for criticality safety and facilitates access for moving and characterization measurements. Measurements were conducted under Westinghouse Hanford Company (WHC) Work Plan SW-WP-0078 for working in and around the trench. The Pacific Northwest Laboratory furnished all measurement equipment and qualified measurement personnel. The Pacific Northwest Laboratory NDA van was used to move equipment and personnel to the measurement site. The van is a self-contained RV with its own electrical generator, on-board computers, and necessary ancillary equipment. Westinghouse Hanford Company provided the crane operators, health physics technicians, riggers, and other ground-support operations personnel for the cask characterization.

Cask-handling and measurement sequence was basically conducted as follows: 
1. Using a crane, each cask was lifted straight up, maintaining the $1.5 \mathrm{~m}(5 \mathrm{ft})$ criticality-spacing criterion, and placed on the counting pad located on the south side of the trench. A taut cable was kept on the cask at all times to prevent possible toppling during measurement. Far-field neutron and gamma measurements were done. Counting time was approximately 10 minutes per cask.

2. After the count was completed, each cask was returned to its original position on the asphalt pad.

Other activities included WHC radiological control personnel smearing each cask for external contamination, dose-rating each cask, visually inspecting casks for integrity, and making cask identifications and assigning TID numbers. 



\subsection{Analysis of Data}

Results of measurements, by PNL personnel, on 37 EBRII casks are presented in Tables 3.1, 3.2, and 3.3. Neutron and gamma spectral measurements were taken on the 36 casks in trench $218-W 4 C-$ $200 \mathrm{~W}$ and one in the 327 Building 300 Area. The experimental irradiated spent fuel specimens were generated as part of the mixed oxide fuel and breeder programs. As such, the casks contain a variety of plutonium and uranium fuel loadings in the same cask. This presents some challenging problems in quantifying 10 CFR 61 radionuclides as well as

Table 3.1. Neutron and Gamma Measurement Results

\begin{tabular}{|c|c|c|c|c|c|c|c|c|c|c|c|c|c|}
\hline IDA No. & Sample No. & TID No. & $\begin{array}{l}\text { Cont. } \\
\text { No. }\end{array}$ & $\begin{array}{c}\text { FS WL } \\
(\mathrm{g})\end{array}$ & $\begin{array}{c}\text { Neutron } \\
\text { Counts }\end{array}$ & \begin{tabular}{|l|} 
Neutron \\
Detector \\
Distance \\
\end{tabular} & $\mathrm{Cts} / \mathrm{Sec}$ & $\begin{array}{c}\text { Corr } \\
\text { Cts/Sec }\end{array}$ & $\begin{array}{c}{ }^{200} \mathrm{Pu} \\
\text { Effective }\end{array}$ & $\begin{array}{l}\text { NDA } \\
\text { No. }\end{array}$ & \begin{tabular}{|l|} 
Gamma \\
Detector \\
Distance \\
\end{tabular} & $\begin{array}{l}{ }^{137} \mathrm{Cs} \\
\text { Net } \\
\text { Area }\end{array}$ & $\begin{array}{l}{ }^{10} \mathrm{Cs} \\
\text { Curies } \\
\end{array}$ \\
\hline & SN065 & & $300-24$ & 2267.0 & 190367 & 17.0 & 905.1 & 260.5 & 66.4 & & 17 & 1567 & 672 \\
\hline A94171 & SN056 & BNW-553 & $300-09$ & & 234566 & 15.8 & 2283.3 & 594.8 & 150.6 & A94171 & 15.75 & 2054 & 1197 \\
\hline A94173 & SN057 & PNL-554 & $300-08$ & & 97596 & 38.5 & 913.6 & 885.2 & 186.1 & A94173 & 15.75 & 2843 & 1657 \\
\hline A94174 & SN010 & PNL-437 & $300-06$ & 3295.3 & 66586 & 38.5 & 603.5 & 584.8 & 123.3 & A94174 & 15.75 & 3584 & 2088 \\
\hline $\mathrm{A} 94175$ & SNOSO & PNL-438 & $300-07$ & 3370.3 & 74372 & 38.8 & 681.3 & 667.2 & 133.4 & A94175 & 15.75 & 3628 & 2114 \\
\hline A94176 & SN009 & PNL-433 & $300-05$ & 3301.0 & 60649 & 38.0 & 544.1 & 516.1 & 110.9 & A94176 & 15.75 & 4317 & 2516 \\
\hline A94177 & SN058 & PNL-588 & $300-18$ & 3962.0 & 33899 & 38.5 & 276.6 & 268.0 & 62.7 & A94177 & 15.75 & 3890 & 2267 \\
\hline A94178 & SN069 & BNW18943 & $300-25$ & 1756.0 & 21778 & 38.5 & 155.4 & 150.6 & 30.4 & A94178 & 15.75 & 1663 & 969 \\
\hline$A 94179^{\circ}$ & SN018 & & $300-04$ & 3152.0 & 57280 & 38.5 & 510.4 & 494.6 & 106.5 & A94179 & 15.75 & 3344 & 1949 \\
\hline A94180 & SN066 & PNL22051 & $300-22$ & 3776.0 & 72760 & 38.5 & 665.2 & 644.6 & 97.2 & A94180 & 15.5 & 2229 & 1273 \\
\hline A94181 & SNO08 & & $300-02$ & 3505.0 & 84777 & 38.5 & 785.4 & 761.0 & 149.6 & A94181 & 15.75 & 1597 & 931 \\
\hline A94182 & SNO68 & PNL-583 & $300-21$ & 3902.0 & 37935 & 38.5 & 317.0 & 307.1 & 70.2 & A94182 & 15.75 & 5663 & 3300 \\
\hline $\mathrm{A} 94183$ & SNO07 & PNL-379 & $300-03$ & 3874.0 & 78606 & 38.5 & 723.7 & 701.2 & 151.6 & A94183 & 15.75 & 3903 & 2274 \\
\hline A94184 & SN070 & PNL22052 & $300-23$ & 3784.0 & 35317 & 38.5 & 290.8 & 281.8 & 36.3 & A94184 & 15.75 & 2599 & 1515 \\
\hline A94185 & SNO59 & PNL-587 & $300-19$ & 3993.0 & 41038 & 38.5 & 348.0 & 337.2 & 76.0 & A94185 & 15.75 & 4495 & 2619 \\
\hline A94186 & SN063 & PNL-561 & $300-15$ & 1679.0 & 66057 & 30.0 & 567.1 & 369.6 & 100.7 & A94186 & 19 & 131 & 98 \\
\hline A94187 & $16538-4$ & HED17065 & & & 57190 & 30.0 & 478.5 & 311.8 & 72.0 & A94187 & 19. & 3264 & 2440 \\
\hline A94188 & SN062 & PNL-566 & $300-14$ & 2238.0 & 60897 & 31.0 & 515.5 & 353.5 & 133.7 & A94188 & 18.75 & 126 & 93 \\
\hline A94190 & SNO52 & PNL-573 & $300-10$ & 3569.0 & 112318 & 31.5 & 1029.7 & 724.1 & 154.7 & A94190 & 18.5 & 2783 & 2006 \\
\hline A94192 & SNO60 & PNL-574 & $300-16$ & 3937.0 & 85358 & 31.5 & 760.1 & 534.5 & 131.3 & A94192 & 19 & 이 & 1 \\
\hline A94193 & SN053 & PNL-580 & $300-12$ & 3505.0 & 56818 & 31.5 & 474.7 & 333.8 & 70.2 & A94193 & 19 & 7298 & 5456 \\
\hline A94194 & SN055 & PNL-579 & $300-11$ & 3396.0 & 44167 & 31.0 & 348.2 & 238.8 & 68.7 & A94194 & 19 & 2958 & 2211 \\
\hline A94195 & SNOS1 & PNL22054 & $300-26$ & 2489.0 & 33675 & 30.0 & 243.3 & 158.6 & 34.6 & A94195 & 19 & 2453 & 1834 \\
\hline A94196 & SNO54 & PNL-590 & $300-17$ & 3984.0 & 50377 & 30.0 & 410.3 & 267.4 & 70.3 & A94196 & 18.5 & 4226 & 3046 \\
\hline A94197 & SN061 & PNL-589 & $300-13$ & 3514.0 & 77410 & 30.5 & 680.7 & 455.1 & 131.3 & A94197 & 18.5 & 4572 & 3296 \\
\hline A94198 & SN067 & PNL-586 & $300-20$ & 3985.0 & 39028 & 31.0 & 296.8 & 203.6 & 69.8 & A94198 & 18 & 2480 & 1723 \\
\hline A94199 & 16538-1 & HED14793 & & & 68772 & 30.0 & 594.3 & 387.3 & 95.2 & A94199 & 19.5 & 1230 & 953 \\
\hline A94200 & $16538-3$ & HED14797 & & & 75100 & 30.0 & 657.6 & 428.5 & 105.3 & A94200 & 19 & 2505 & 1873 \\
\hline A94201 & $16538-2$ & HED 14795 & & & 76173 & 29.5 & 668.3 & 424.4 & 104.3 & A94201 & 18 & 1826. & 1268 \\
\hline A94172 & SNO12 & WHC22372 & & & 1745238 & 39.0 & 17390.0 & 17209.3 & 4228.3 & A94172 & 19 & 2054 & 1536 \\
\hline A94189 & SNOII & WHC22369 & & & 1504942 & 31.5 & 14956.0 & 10516.3 & 2583.9 & A94189 & 18.25 & 3135 & 2219 \\
\hline A94191 & SN015 & WHC22374 & & & 1771263 & 31.0 & 17619.2 & 12083.1 & 2968.8 & A94191 & 19 & 2542 & 1900 \\
\hline A94202 & SN016 & WHC22371 & & & 1419948 & 29.0 & 14106.0 & 8724.8 & 2143.7 & A94202 & 19 & 2193 & 1639 \\
\hline A94203 & SN014 & WHC22370 & & & 1493966 & 30.0 & 14846.2 & 9675.6 & 2377.3 & A94203 & 19. & 2332 & 2193 \\
\hline A94204 & SNO13 & WHC22373 & & & 2362209 & 31.0 & 23528.7 & 16135.7 & 3964.6 & A94204 & 18.75 & 3169 & 2327 \\
\hline A94205 & 17035 & NONE & & 73.5 & 1034051 & 84.0 & 10247.1 & 38260.0 & 9400.5 & A94205 & 44.5 & 785 & 2161 \\
\hline A94205 & 17035 & NONE & & 73.5 & 2709408 & 43.5 & 27000.6 & 31993.7 & 7860.9 & A94205 & & & \\
\hline A94206 & |PNL186028 & PNL17608 & & & 9897| & 84 & 5.5 & 20.6 & & A94206 & 44.5 & 12974 & 35715 \\
\hline
\end{tabular}


Table 3.2. Nontransuranic Curie Content from Gamma Measurements

\begin{tabular}{|c|c|c|c|c|c|c|c|}
\hline \multirow[b]{2}{*}{ NDA No. } & \multirow[b]{2}{*}{ Sample No. } & \multirow[b]{2}{*}{ TID No. } & \multirow{2}{*}{$\begin{array}{c}\text { Contd. } \\
\text { No. }\end{array}$} & \multicolumn{4}{|c|}{ Curies } \\
\hline & & & & ${ }^{137} \mathrm{Cs}$ & ${ }^{154} \mathrm{Eu}$ & ${ }^{60} \mathrm{Co}$ & ${ }^{134} \mathrm{Cs}$ \\
\hline & SN065 & & $300-24$ & 672 & 1.2 & 2.1 & 0.0 \\
\hline A94171 & SN056 & BNW-553 & & 1197 & 14.7 & 0.4 & 10.8 \\
\hline A94173 & SN057 & PNL-554 & $300-08$ & 1657 & 2.2 & 0.5 & 0.7 \\
\hline A94174 & SN010 & PNL-437 & $300-06$ & 2088 & 2.8 & 0.6 & 0.4 \\
\hline A94175 & SN050 & PNL-438 & $300-07$ & 2114 & 2.8 & 0.5 & 0.0 \\
\hline A94176 & SN009. & PNL-433 & $300-05$ & 2516 & 3.0 & 0.7 & 0.8 \\
\hline A94177 & SN058 & PNL-588 & $300-18$ & 2267 & 2.3 & 0.6 & 0.8 \\
\hline A94178 & SN069 & BNW18943 & $300-25$ & 969 & 0.8 & 0.8 & 0.0 \\
\hline A94179 & SN018 & & $300-04$ & 1949 & 4.2 & 0.8 & 2.0 \\
\hline A94180 & SN066 & PNL22051 & $300-22$ & 1273 & 1.8 & 0.4 & 0.0 \\
\hline A94181 & SN008 & & $300-02$ & 931 & 0.7 & 0.2 & 0.0 \\
\hline A94182 & SN068 & PNL-583 & $300-21$ & 3300 & 3.4 & 0.4 & 2.8 \\
\hline A94183 & SN007 & PNL-379 & $300-03$ & 2274 & 2.5 & 0.6 & 0.0 \\
\hline A94184 & SN070 & PNL22052 & $300-23$ & 1515 & 1.2 & 0.1 & 0.0 \\
\hline A94185 & SN059 & PNL-587 & $300-19$ & 2619 & 2.8 & 0.3 & 1.6 \\
\hline A94186 & SN063 & PNL-561 & $300-15$ & 98 & 0.0 & 0.0 & 0.0 \\
\hline A94187 & $16538-4$ & HED17065 & & 2440 & 2.1 & 0.9 & 0.0 \\
\hline A94188 & SN062. & PNL-566 & $300-14$ & 93 & 0.0 & 0.0 & 0.0 \\
\hline A94190 & SNO52 & PNL-573 & $300-10$ & 2006 & 6.0 & 0.7 & 3.3 \\
\hline A94192 & SN060 & PNL-574 & $300-16$ & 0 & 0.0 & 0.2 & 0.0 \\
\hline A94193 & SN053 & PNL-580 & $300-12$ & 5456 & 7.9 & 1.5 & 4.7 \\
\hline A94194 & SN055 & PNL-579 & $300-11$ & 2211 & 1.5 & 0.5 & 0.4 \\
\hline A94195 & SN051 & PNL22054 & $300-26$ & 1834 & 1.5 & 0.1 & 0.5 \\
\hline A94196 & SN054 & PNL-590 & $300-17$ & 3046 & 3.2 & 0.3 & 1.4 \\
\hline A94197 & SN061 & PNL-589 & $300-13$ & 3296 & 4.3 & 2.0 & 4.0 \\
\hline A94198 & SN067 & PNL-586 & $300-20$ & 1723 & 0.9 & 0.1 & 0.0 \\
\hline A94199 & 16538-1 & HED14793 & & 953 & 0.5 & 0.2 & 0.0 \\
\hline A94200 & 16538-3 & HED14797 & & 1873 & 1.1 & 0.2 & 0.0 \\
\hline A94201 & $16538-2$ & HED14795 & & 1268 & 1.1 & 0.2 & 0.0 \\
\hline A94172 & SN012 & WHC22372 & & 1536 & 19.0 & 0.5 & 13.9 \\
\hline A94189 & SN011 & WHC22369 & & 2219 & 22.2 & 0.6 & 10.5 \\
\hline A94191 & SN015 & WHC22374 & & 1900 & 14.6 & 1.4 & 8.1 \\
\hline A94202 & SN016 & WHC22371 & & 1639 & 17.5 & 0.4 & 12.1 \\
\hline A94203 & SN014 & WHC22370 & & 2193 & 20.6 & 0.3 & 14.1 \\
\hline A94204 & SN013 & WHC22373 & & 2327 & 22.0 & 1.3 & 16.8 \\
\hline A94205 & 17035 & NONE & & 2161 & 30.5 & 12.4 & 0.0 \\
\hline A94206 & PNL186028 & PNL17608 & & 35715 & 43.3 & 4.7 & 0.0 \\
\hline
\end{tabular}


Table 3.3. Nontransuranic Curies Based on ${ }^{137} \mathrm{Cs}$ Burn-up Estimates and ISOGEN Calculations

\begin{tabular}{|c|c|c|c|c|c|c|c|c|c|c|c|}
\hline \multirow[b]{2}{*}{ NDA No. } & \multirow[b]{2}{*}{ Sample No. } & \multirow[b]{2}{*}{ TID No. } & \multirow[b]{2}{*}{$\begin{array}{c}\text { Cont. } \\
\text { No. }\end{array}$} & \multicolumn{8}{|c|}{ Curies } \\
\hline & & & & ${ }^{154} \mathrm{Eu}$ & ${ }^{152} \mathrm{Sm}$ & ${ }^{117} \mathrm{Pm}$ & ${ }^{137} \mathrm{Cs}$ & ${ }^{90} \mathrm{Y}$ & ${ }^{90} \mathrm{Sr}$ & ${ }^{25} \mathrm{Kr}$ & Total Curies \\
\hline & SN065 & & $300-24$ & 1.5 & 41.2 & 124.1 & 672.0 & 318.9 & 318.8 & 24.8 & 1501.3 \\
\hline A94171 & SN056 & BNW-553 & & 2.8 & 73.3 & 221.1 & 1197.0 & 568.1 & 567.9 & 44.1 & 2674.2 \\
\hline A94173 & SN057 & PNL-554 & $300-08$ & 3.8 & 101.5 & 306.1 & 1657.0 & 786.4 & 786.1 & 61.0 & 3701.9 \\
\hline A94174 & SNO1O & PNL-437 & $300-06$ & 4.8 & 127.9 & 385.7 & 2088.0 & 990.9 & 990.6 & 76.9 & 4664.9 \\
\hline A94175 & SNO50 & PNL-438 & $300-07$ & 4.9 & 129.5 & 390.5 & 2114.0 & 1003.2 & 1003.0 & 77.9 & 4722.9 \\
\hline A94176 & SNOO9 & PNL-433 & $300-05$ & 5.8 & 154.1 & 464.8 & 2516.0 & 1194.0 & 1193.7 & 92.7 & 5621.1 \\
\hline A94177 & SN058 & PNL-588 & $300-18$ & 5.2 & 138.9 & 418.8 & 2267.0 & 1075.9 & 1075.6 & 83.5 & 5064.8 \\
\hline A94178 & SN069 & BNW 18943 & $300-25$ & 2.2 & 59.4 & 179.0 & 969.0 & 459.9 & 459.7 & 35.7 & 2164.9 \\
\hline A94179 & SN018 & & $300-04$ & 4.5 & 119.4 & 360.0 & 1949.0 & 924.9 & 924.7 & 71.8 & 4354.3 \\
\hline A94180 & SN066 & PNL22051 & $300-22$ & 2.9 & 78.0 & 235.2 & 1273.0 & 604.1 & 604.0 & 46.9 & 2844.0 \\
\hline A94181 & SN008 & & $300-02$ & 2.1 & 57.0 & 172.0 & 931.0 & 441.8 & 441.7 & 34.3 & 2080.0 \\
\hline A94182 & SN068 & PNL-583 & $300-21$ & 7.6 & 202.2 & 609.6 & 3300.0 & 1566.1 & 1565.7 & 121.5 & 7372.6 \\
\hline A94183 & SN007 & PNL-379 & $300-03$ & 5.2 & 139.3 & 420.1 & 2274.0 & 1079.2 & 1078.9 & 83.8 & 5080.4 \\
\hline A94184 & SNO70 & PNL22052 & $300-23$ & 3.5 & 92.8 & 279.9 & 1515.0 & 719.0 & 718.8 & 55.8 & 3384.7 \\
\hline A94185 & SN059 & PNL-587 & $300-19$ & 6.0 & 160.4 & 483.8 & 2619.0 & 1242.9 & 1242.6 & 96.5 & 5851.2 \\
\hline A94186 & SN063 & PNL-561 & $300-15$ & 0.2 & 6.0 & 18.1 & 98.0 & 46.5 & 46.5 & 3.6 & 218.9 \\
\hline A94187 & $16538-4$ & HED17065 & & 5.6 & 149.5 & 450.7 & 2440.0 & 1158.0 & 1157.6 & 89.9 & 5451.3 \\
\hline A94188 & SNO62 & PNL-566 & $300-14$ & 0.2 & 5.7 & 17.2 & 93.0 & 44.1 & 44.1 & 3.4 & 207.8 \\
\hline A94190 & SN052 & PNL-573 & $300-10$ & 4.6 & 122.9 & 370.6 & 2006.0 & 952.0 & 951.7 & 73.9 & 4481.7 \\
\hline A94192 & SNO60 & PNL-574 & $300-16$ & 0.0 & 0.0 & 0.0 & 0.0 & 0.0 & 0.0 & 0.0 & 0.0 \\
\hline A94193 & SN053 & PNL-580 & $300-12$ & 12.5 & 334.2 & 1007.8 & 5456.0 & 2589.3 & 2588.6 & 200.9 & 12189.4 \\
\hline A94194 & SN055 & PNL-579 & $300-11$ & 5.1 & 135.4 & 408.4 & 2211.0 & 1049.3 & 1049.0 & 81.4 & 4939.7 \\
\hline A94195 & SN051 & PNL22054 & $300-26$ & 4.2 & 112.4 & 338.8 & 1834.0 & 870.4 & 870.1 & 67.5 & 4097.4 \\
\hline A94196 & SN054 & PNL-590 & $300-17$ & 7.0 & 186.6 & 562.7 & 3046.0 & 1445.5 & 1445.1 & 112.2 & 6805.2 \\
\hline A94197 & SN061 & PNL-589 & $300-13$ & 7.6 & 201.9 & 608.8 & 3296.0 & 1564.2 & 1563.8 & 121.4 & 7363.7 \\
\hline A94198 & SN067 & PNL-586 & $300-20$ & 4.0 & 105.6 & 318.3 & 1723.0 & 817.7 & 817.5 & 63.5 & 3849.4 \\
\hline A94199 & $16538-1$ & HED14793 & & 2.2 & 58.4 & 176.0 & 953.0 & 452.3 & 452.1 & 35.1 & 2129.1 \\
\hline A94200 & 16538-3 & HED14797 & & 4.3 & 114.7 & 346.0 & 1873.0 & 888.9 & 888.6 & 69.0 & 4184.5 \\
\hline A94201 & $16538-2$ & HED14795 & & 2.9 & 77.7 & 234.2 & 1268.0 & 601.8 & 601.6 & 46.7 & 2832.9 \\
\hline A94172 & SN012 & WHC22372 & & 3.5 & 94.1 & 283.7 & 1536.0 & 728.9 & 728.7 & 56.6 & 3431.6 \\
\hline A94189 & SN011 & WHC22369 & & 5.1 & 135.9 & 409.9 & 2219.0 & 1053.1 & 1052.8 & 81.7 & 4957.5 \\
\hline A94191 & SN015 & WHC22374 & & 4.4 & 116.4 & 351.0 & 1900.0 & 901.7 & 901.4 & 70.0 & 4244.8 \\
\hline A94202 & SN016 & WHC22371 & & 3.8 & 100.4 & 302.8 & 1639.0 & 777.8 & 777.6 & 60.4 & 3661.7 \\
\hline A94203 & SN014 & WHC22370 & & 5.0 & 134.3 & 405.1 & 2193.0 & 1040.7 & 1040.4 & 80.8 & 4899.4 \\
\hline A94204 & SN013 & WHC22373 & & 5.3 & 142.6 & 429.8 & 2327.0 & 1104.3 & 1104.0 & 85.7 & 5198.8 \\
\hline A94205 & 17035 & NONE & & 5.0 & 132.4 & 399.2 & 2161.0 & 1025.6 & 1025.3 & 79.6 & 4827.9 \\
\hline \multirow[t]{2}{*}{ A94206 } & PNL186028 & PNL17608 & & 82.1 & 2188.0 & 6597.3 & 35715.0 & 16949.4 & 16944.7 & 1315.4 & 79791.8 \\
\hline & & & \begin{tabular}{|l} 
Total \\
Percent
\end{tabular} & $\begin{array}{r}237.5 \\
0.1 \\
\end{array}$ & $\begin{array}{r}6330.0 \\
2.7 \\
\end{array}$ & $\begin{array}{r}19087.0 \\
8.3 \\
\end{array}$ & $\begin{array}{r}103328.0 \\
44.8 \\
\end{array}$ & $\begin{array}{r}49036.7 \\
21.2 \\
\end{array}$ & $\begin{array}{r}49023.1 \\
21.2 \\
\end{array}$ & $\begin{array}{r}3805.6 \\
1.6 \\
\end{array}$ & $\begin{array}{r}230847.9 \\
100.0 \\
\end{array}$ \\
\hline
\end{tabular}


determining burn-up information from gamma spectral data. The ${ }^{134} \mathrm{Cs} /{ }^{137} \mathrm{Cs}$ ratios are generally used to indicate fuel burn-up values. However, in this case, just the ${ }^{137} \mathrm{Cs}$ was used to determine burn-up. Data on time since discharge was not known for these casks; therefore, back-calculating to the time of removal from the reactor (time zero) for ${ }^{134} \mathrm{Cs}$ was not possible. Burn-up values were determined by comparing the total curies of ${ }^{137} \mathrm{Cs}$ per gram quantity of ${ }^{238} \mathrm{U}$ present in the fuel to the curies generated per megawatt days/metric ton of fuel, as calculated by the computer code ISOGEN. It was assumed that there were 5000 days post-irradiation and $25 \%$ plutonium/natural uranium mixed oxide fuel. This information was used to determine the quantity of 10 CFR 61 radionuclides present in the spent fuel. One cask, \#SN065 (container number 300-24), was stored in the 327 Building in the 300 Area.

\subsection{Results of Neutron Measurements}

Plutonium and uranium quantities were taken from shippers' values. This data provided ${ }^{240} \mathrm{Pu}$ weight percent values, grams of plutonium and uranium, and percent of ${ }^{235} \mathrm{U}$. Verification of SNM was accomplished using neutron measurement data. The neutron data is plotted as neutron counts/second versus grams of ${ }^{240} \mathrm{Pu}$ effective and presented in Figure 3.1. The data has a linear correlation and verifies accepted book values for 29 of the casks.

Seven of the remaining eight casks have extremely high burn-up values and cannot be grouped with the other 29. Seven of these casks contain significant quantities of ${ }^{244} \mathrm{Cm}$, which has a very high neutron yield. From a neutron emission rate standpoint, most of the neutron emissions originate from ${ }^{244} \mathrm{Cm}$; there is simply not sufficient ${ }^{240} \mathrm{Pu}$ present to account for the high neutron emission rates.

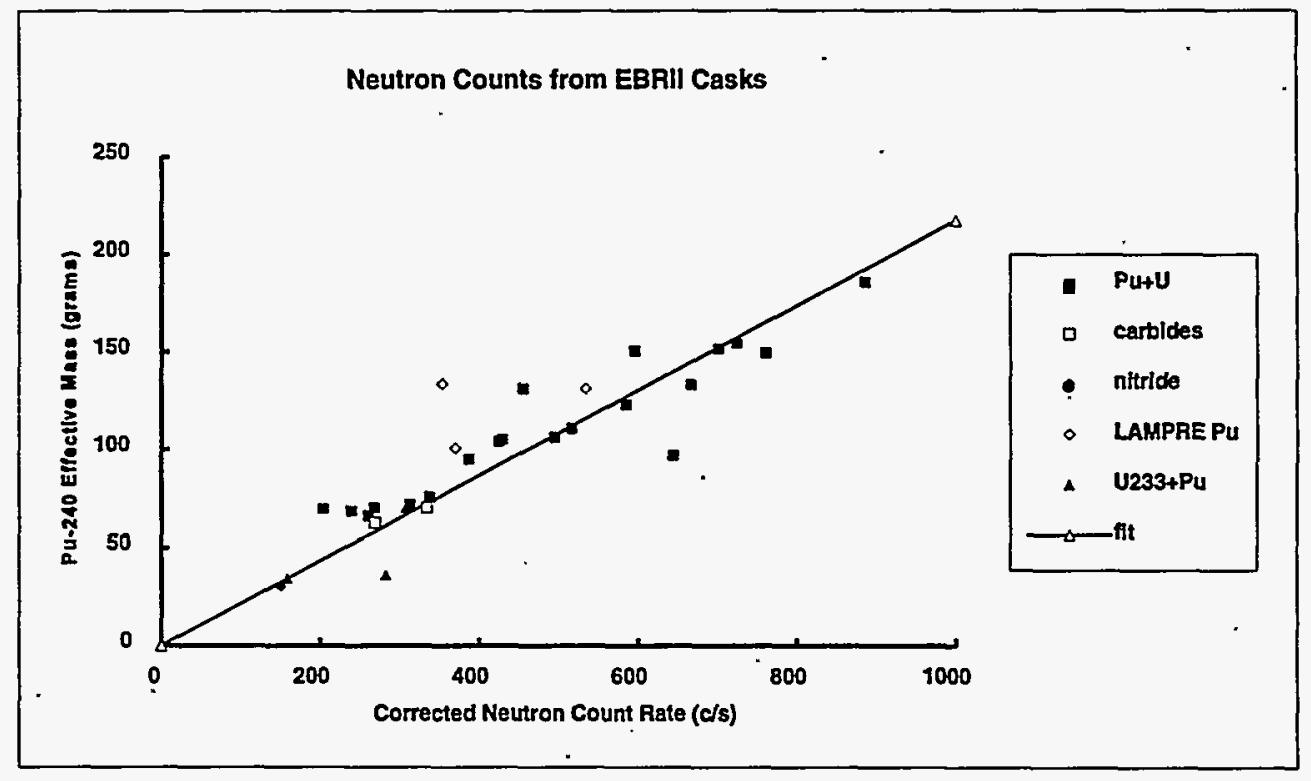

Figure 3.1. Verification of ${ }^{240} \mathrm{Pu}$ Content from Neutron Yield Measurements on EBRII Casks 
In Figure 3.2, the grams of ${ }^{244} \mathrm{Cm}$ are plotted as a function of ${ }^{137} \mathrm{Cs}$. There is a correlation, but not as good as the ${ }^{240} \mathrm{Pu}$ data. The outlier in this data group is NDA Log \#A94205, which contains ${ }^{241} \mathrm{Am}$ target material. Two of the casks have slightly different dimensions from the standard EBRII casks. The cask for NDA Log \#A94205 contains ${ }^{241}$ Am target material and the other cask, \#A94206, contains leached recycled fuel hulls. The seven casks containing recycled fuel have ${ }^{244} \mathrm{Cm}$ in sufficient quantity to totally mask the neutron component from plutonium. The data were corrected to neutrons/second and then divided by $1.08 \times 10^{7}$ neutrons/second/gram of ${ }^{244} \mathrm{Cm}$ to give the mass of ${ }^{244} \mathrm{Cm}$.

Figure 3.3 shows the seven casks plotted with neutron counts as a function of grams of ${ }^{244} \mathrm{Cm}$. The basis for this graph is historical data on cask \#17035-105N, NDA Log \#A94205. This cask has 12 americium target elements, which were irradiated in $\mathrm{K}$ Reactor for 15 months and discharged in September 1970. Quantities reported on the DOE/NRC-741 form were based on physicists' production estimates of $4-\mathrm{g}{ }^{244} \mathrm{Cm}$ on February 28, 1983. Decay corrected to September 1994 gives a value of 2.6-g ${ }^{244} \mathrm{Cm}$. Based on neutron counting, there are $2.4 \mathrm{~g}$ of ${ }^{244} \mathrm{Cm}$. This value is within $10 \%$ of the stated decay-corrected value: Cask \#A94206, containing leached fuel hulls, has the most nontransuranic or fission product activity of all the casks. There is approximately $1 \mathrm{~g}$ of plutonium in \#A94206 by neutron counting.

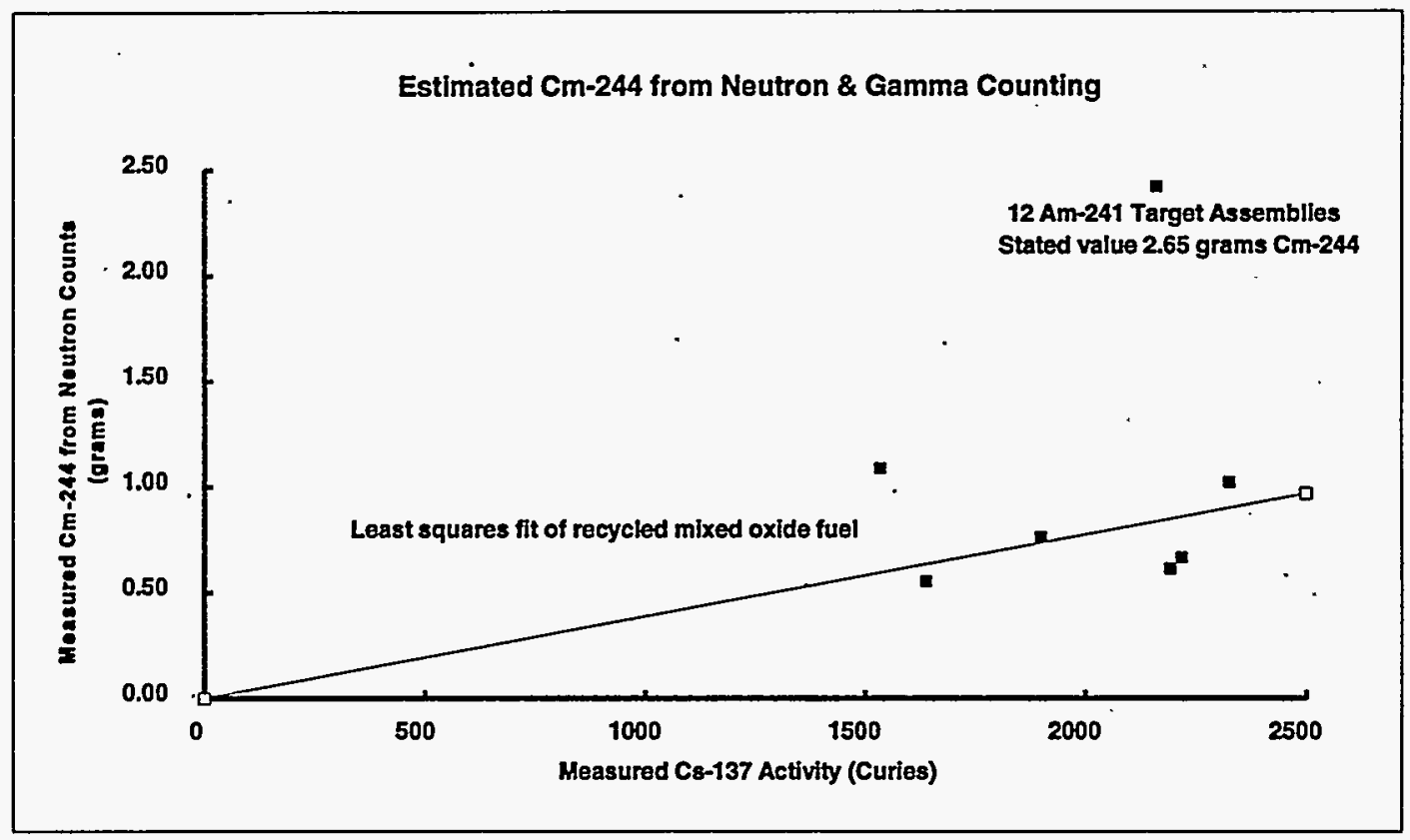

Figure 3.2. Correlation of ${ }^{244} \mathrm{Cm}$ Content from Neutron Counting with Burn-up Estimated by ${ }^{137} \mathrm{Cs}$ Content per Gram of Fuel 


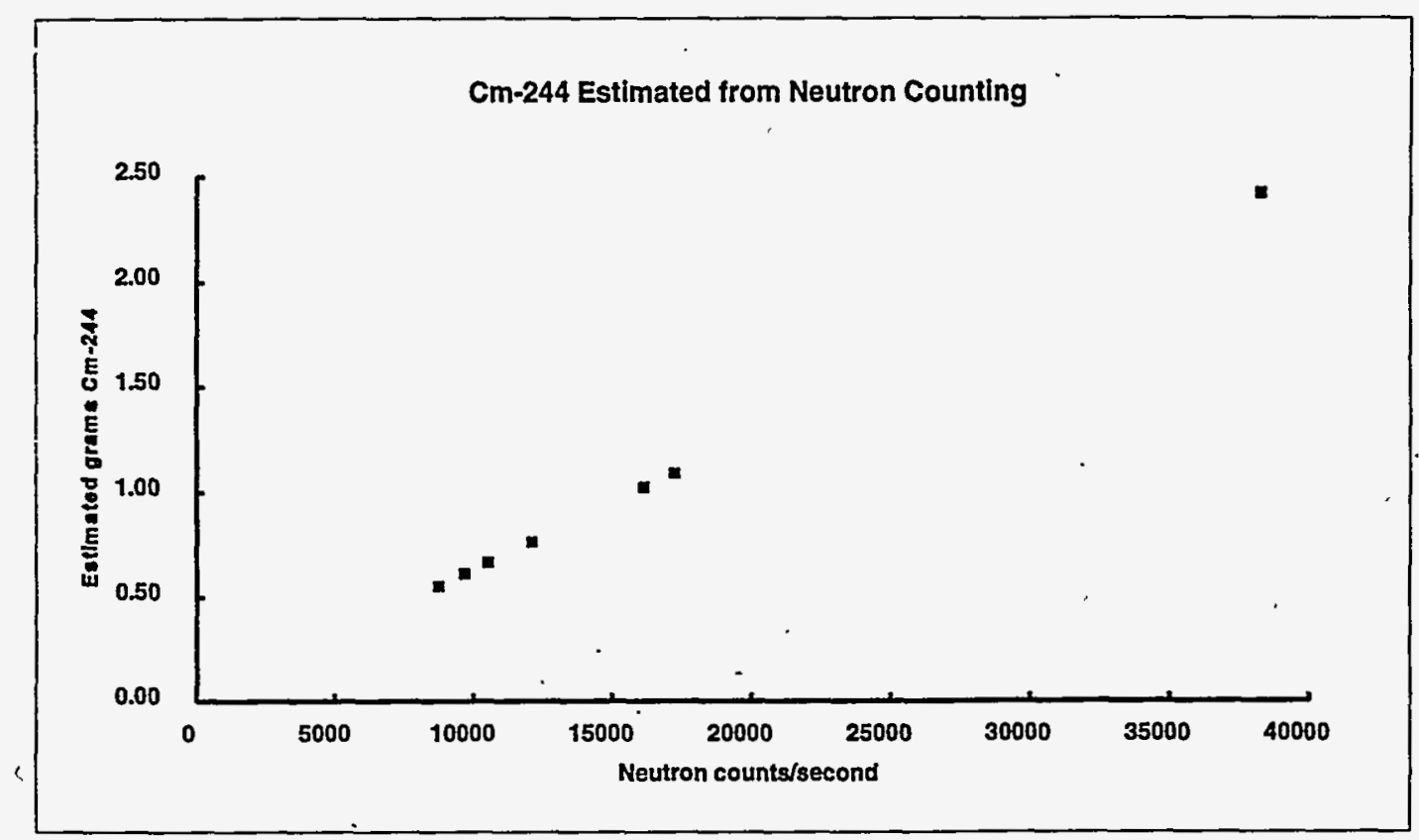

Figure 3.3. Curium-244 Content in Recycled Plutonium Fuels Estimated from Neutron Yield Measurements.

\subsection{Results from Gamma Spectral Data}

Gamma spectra from the cask measurements are presented in Figures 3.4 to 3.8. Table 3.2 lists directly measured curies of ${ }^{137} \mathrm{Cs} ;{ }^{134} \mathrm{Cs},{ }^{154} \mathrm{Eu}$, and ${ }^{60} \mathrm{Co}$. Radionuclides directly identifiable from the gamma spectral data are ${ }^{137} \mathrm{Cs},{ }^{134} \mathrm{Cs},{ }^{60} \mathrm{Co},{ }^{154} \mathrm{Eu}$, and ${ }^{233} \mathrm{U}\left({ }^{208} \mathrm{Tl}\right)$. The ISOGEN code approximation was used for quantifying 10 CFR 61 radionuclides as shown in Table 3.3. The transuranic isotopes and quantities are based on shippers' book values, as listed on DOE/NRC-741 forms. Only radionuclides that contribute $1 \%$ or more to the total activity are listed in Table 3.3 as required in WHC-EP-0063, Rev. 4.

\subsection{Measurements of 2736-ZD Vault}

After the initial inventory verification measurements were completed, three of the EBRII casks containing plutonium fuel elements were moved to the Plutonium Finishing Plant and placed in the 2736-ZD storage vault. This is a storage vault constructed from a concrete cylinder with 8-inch-thick walls and a cap welded in place. It was necessary to confirm that the plutonium fuel elements were still in place without opening the structure, which would have been prohibitively expensive. The attribute measurements were performed using neutron detectors. The same slab neutron detector described previously in Section 2.3 was used to measure the neutron emissions around the circumference of the 




Figure 3.4. Gamma Spectrum of LAMPRE MOX Fuel Cask

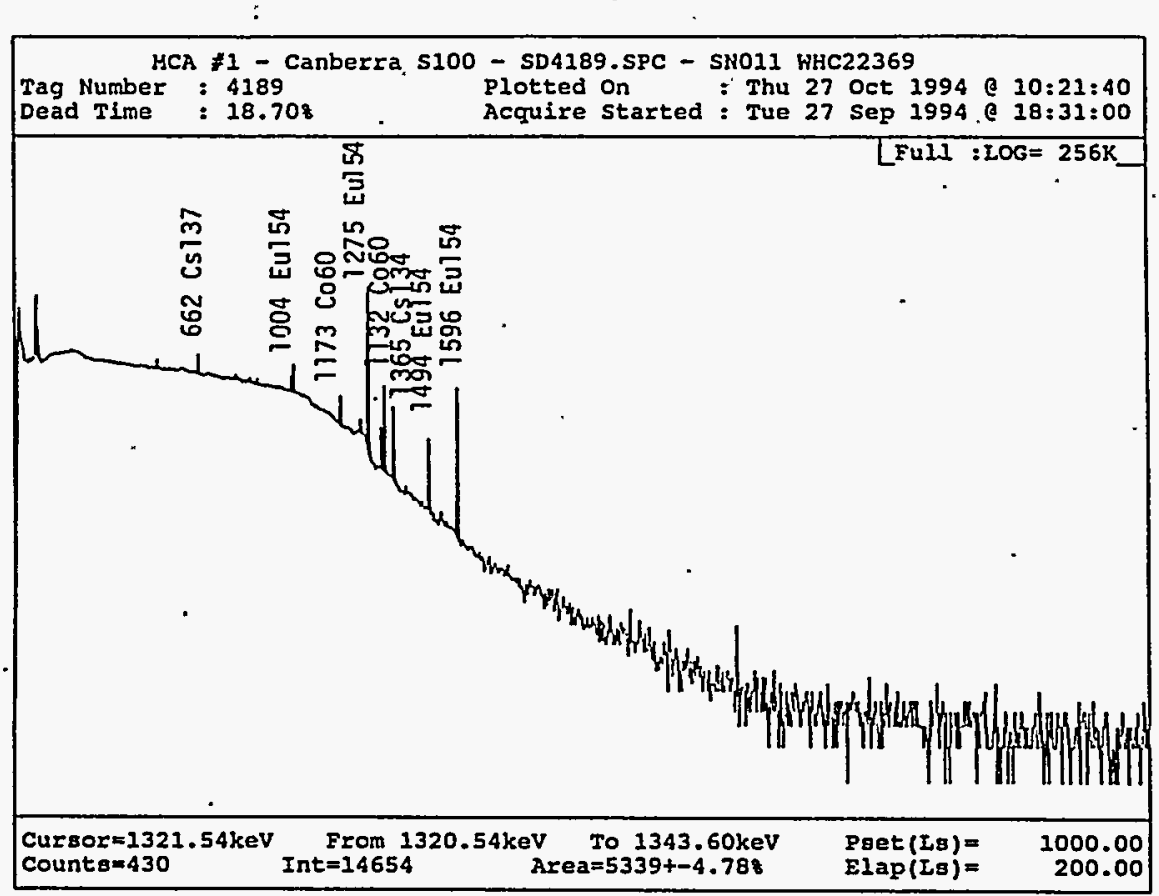

Figure 3.5. Gamma Spectrum of Recycled MOX Fuel 


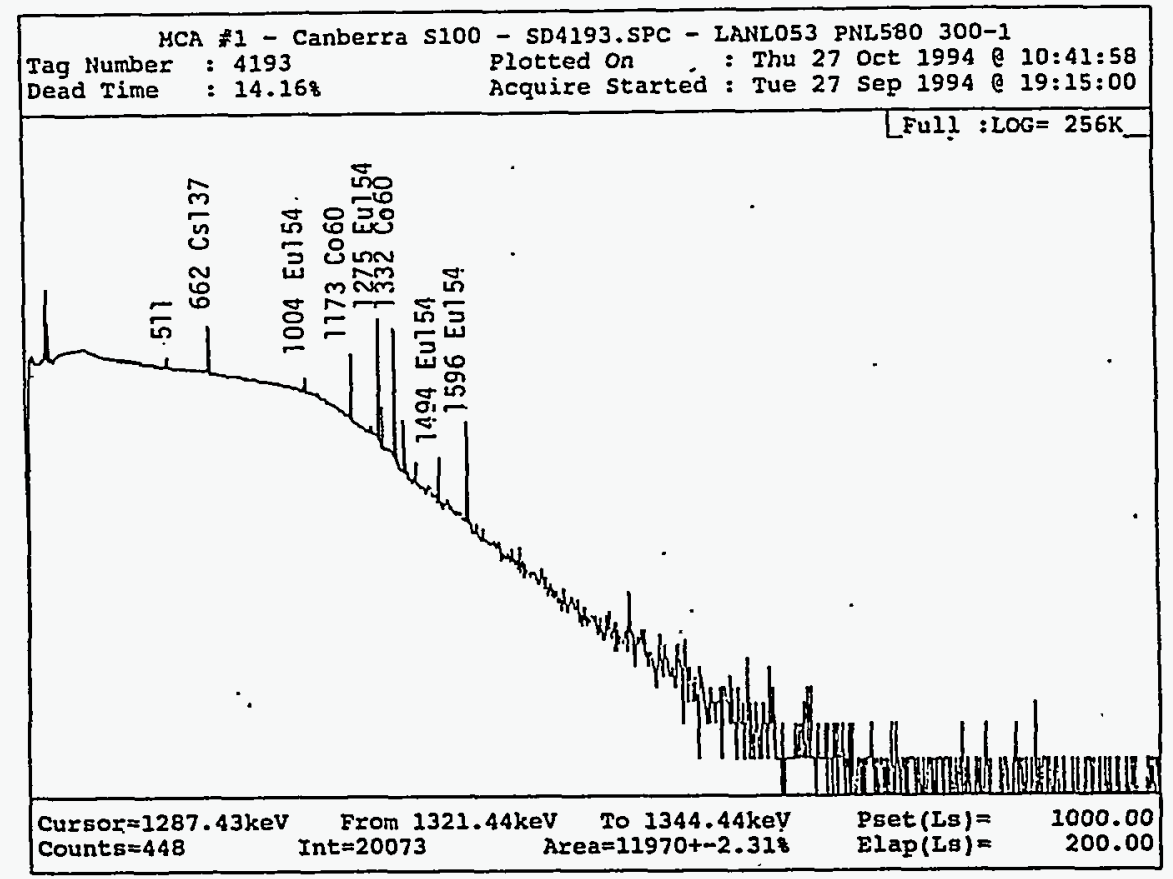

Figure 3.6. Gamma Spectrum of MOX Carbide Fuel Cask



Figure 3.7. Gamma Spèctrum of Irradiated ${ }^{241}$ Am Target Cask 


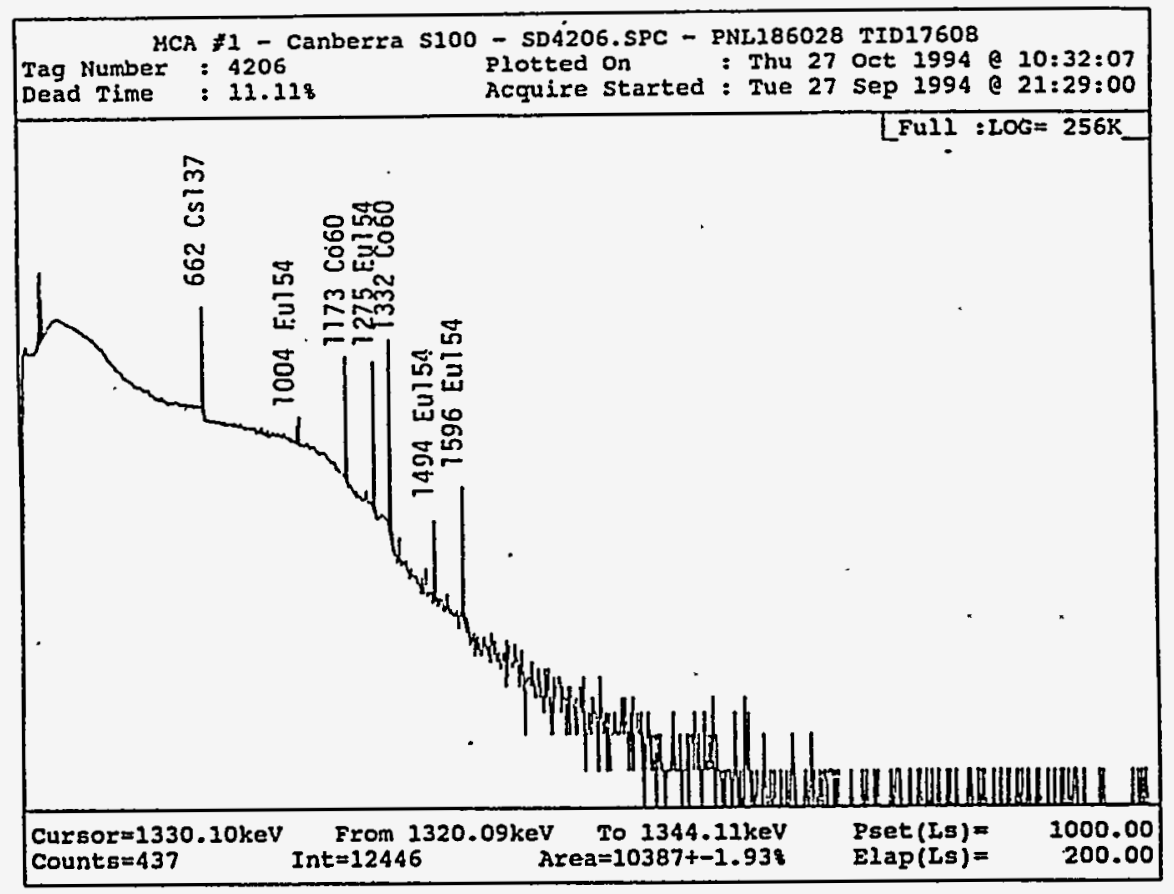

Figure 3.8. Gamma Spectrum of Leached Spent Fuels Hulls Cask

concrete cylinder. The results are presented in Figure 3.9. In this figure, the zero-degree position is at the south side of the structure. The pattern of neutron intensity measured every $30^{\circ}$ shows that three distinct fuel elements are inside the structure. From previous measurements of the neutron emission rates, it is possible to estimate the position of each cask inside the structure. Based on neutron emission rates, cask $300-16$ is on the west side, cask $300-15$ is on the southeast side, and cask $300-14$ is on the north east side. Figure 3.10 shows a cross-sectional view of the estimated locations of each of the three EBRII fuel elements stored inside the $2736-Z D$ vault.

A collimated neutron detector was also used to measure the neutron emission rates. This highly collimated detector responds to fast neutrons. The angular response measured in the laboratory using a ${ }^{252} \mathrm{Cf}$ source is shown in Figure 3.11. The full-width half maximum (FWHM) of the relative response is only $24^{\circ}$ wide, which is quite reasonable for fission neutrons. The collimated neutron detector was positioned on the southwest side of the structure, as shown in Figure 3.10, and the assembly rotated in $15^{\circ}$ increments. The results are shown in Figure 3.12, which shows three distinct peaks corresponding to the three fuel elements. This is remarkable resolution, considering that the neutrons have passed through more than $20 \mathrm{~cm}$ ( $8 \mathrm{in}$.) of concrete and are highly scattered. The collimated detector was able to identify the three individual fuel elements in a very short time because it was not necessary to move the entire detector assembly around the circumference of the $2736-\mathrm{ZD}$ vault. Future confirmatory measurements can be made quite quickly with this detector. 


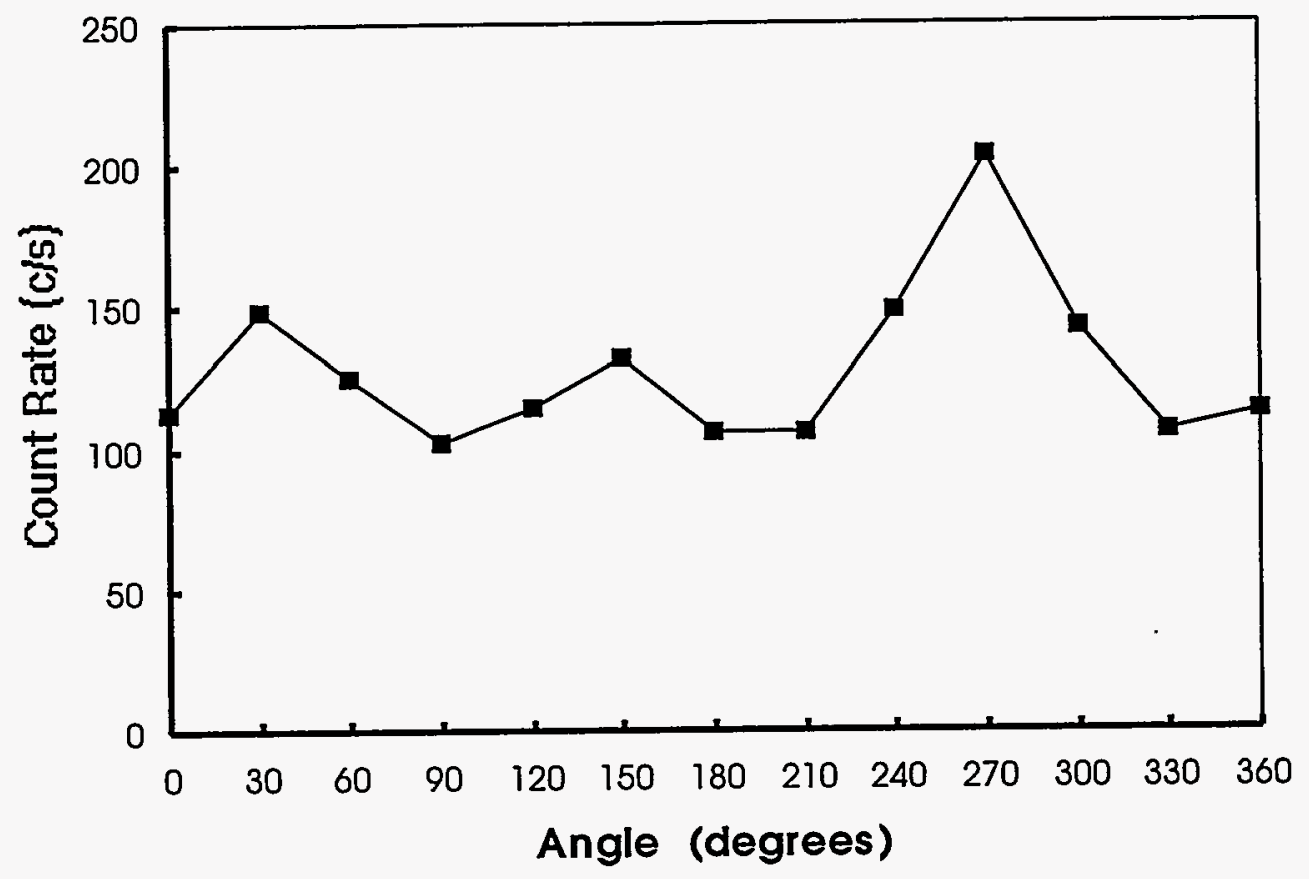

Figure 3.9. Neutron Intensity Measured Around the Circumference of the 2736-ZD Cylindrical Storage Vault Using the Slab Neutron Detector

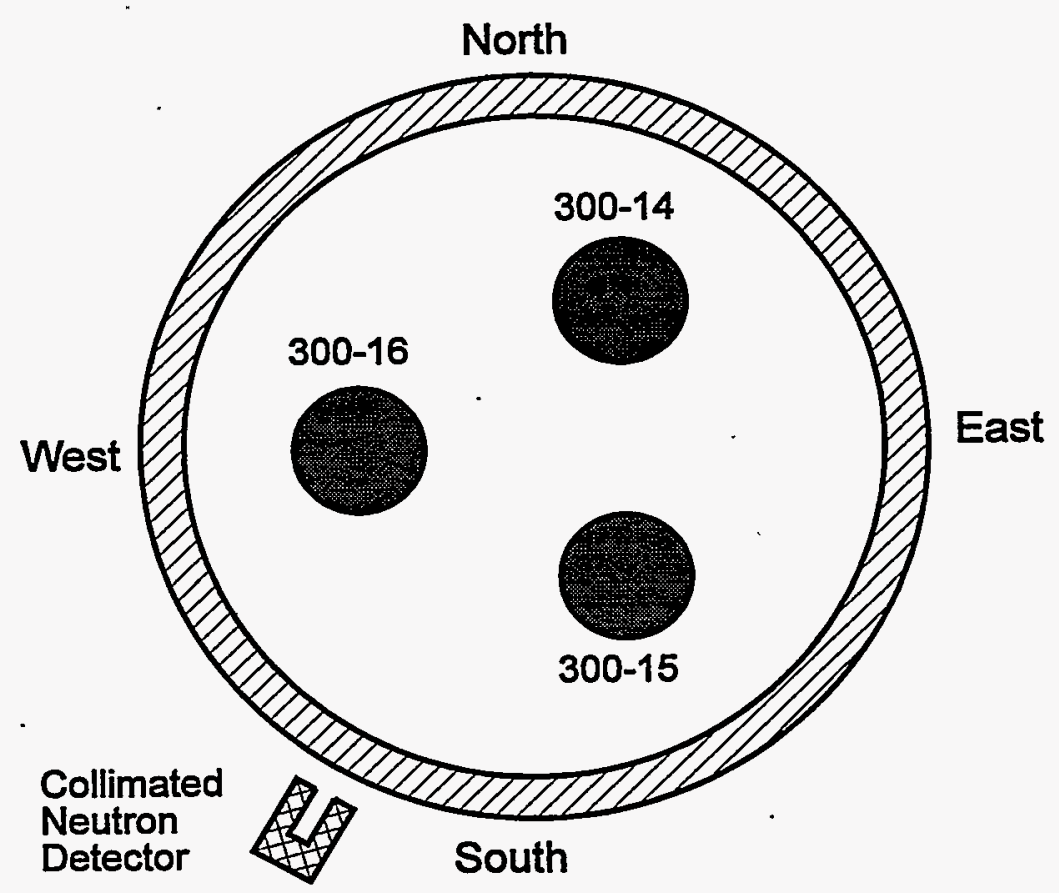

Figure 3.10. Cross-sectional View of 2736-ZD Storage Vault Showing the Position of Three EBRII Spent Fuel Casks Estimated from Neutron Counting 


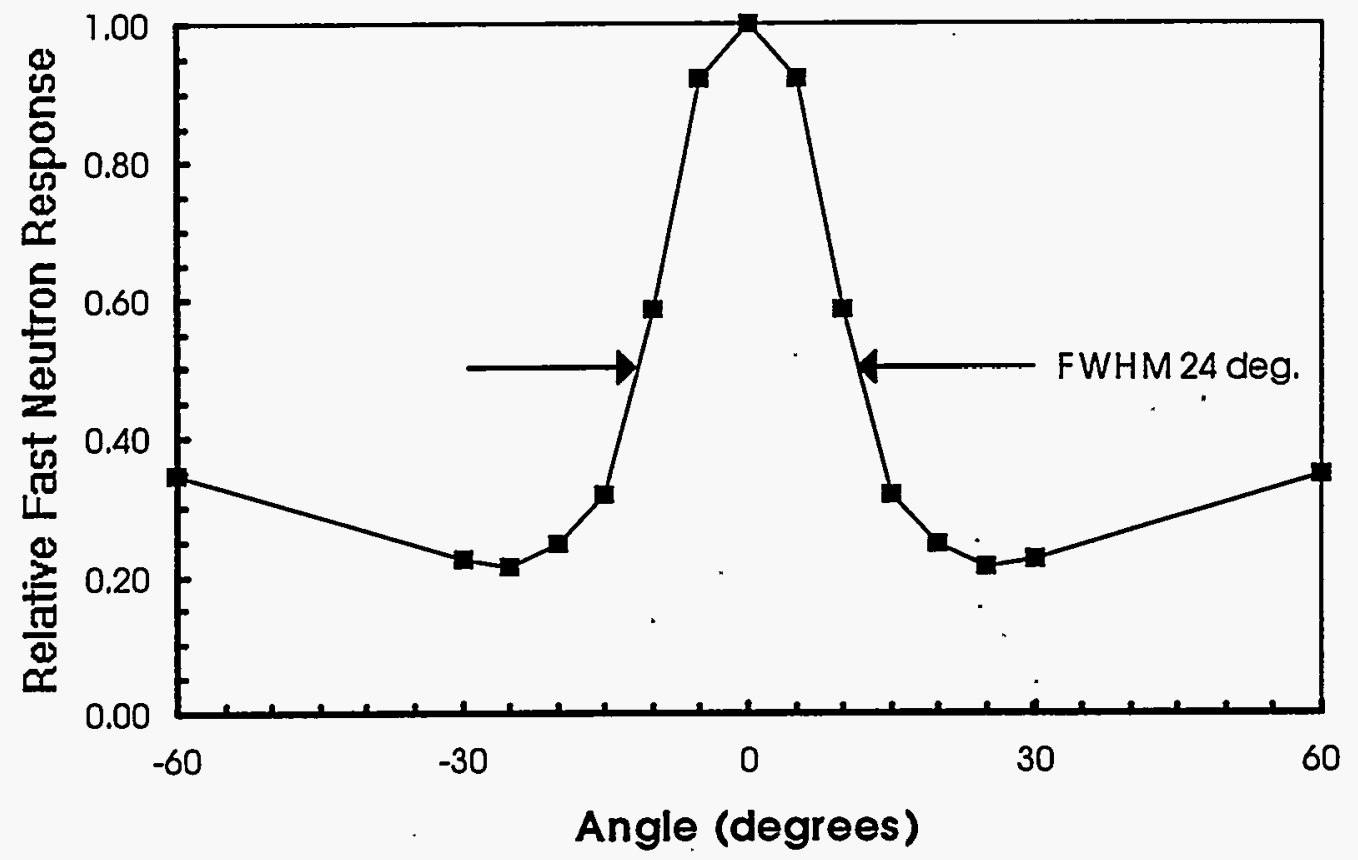

Figure 3.11. Angular response of the Colimated Fast Neutron Detector Measured Using a ${ }^{252} \mathrm{Cf}$ Neutron Source.

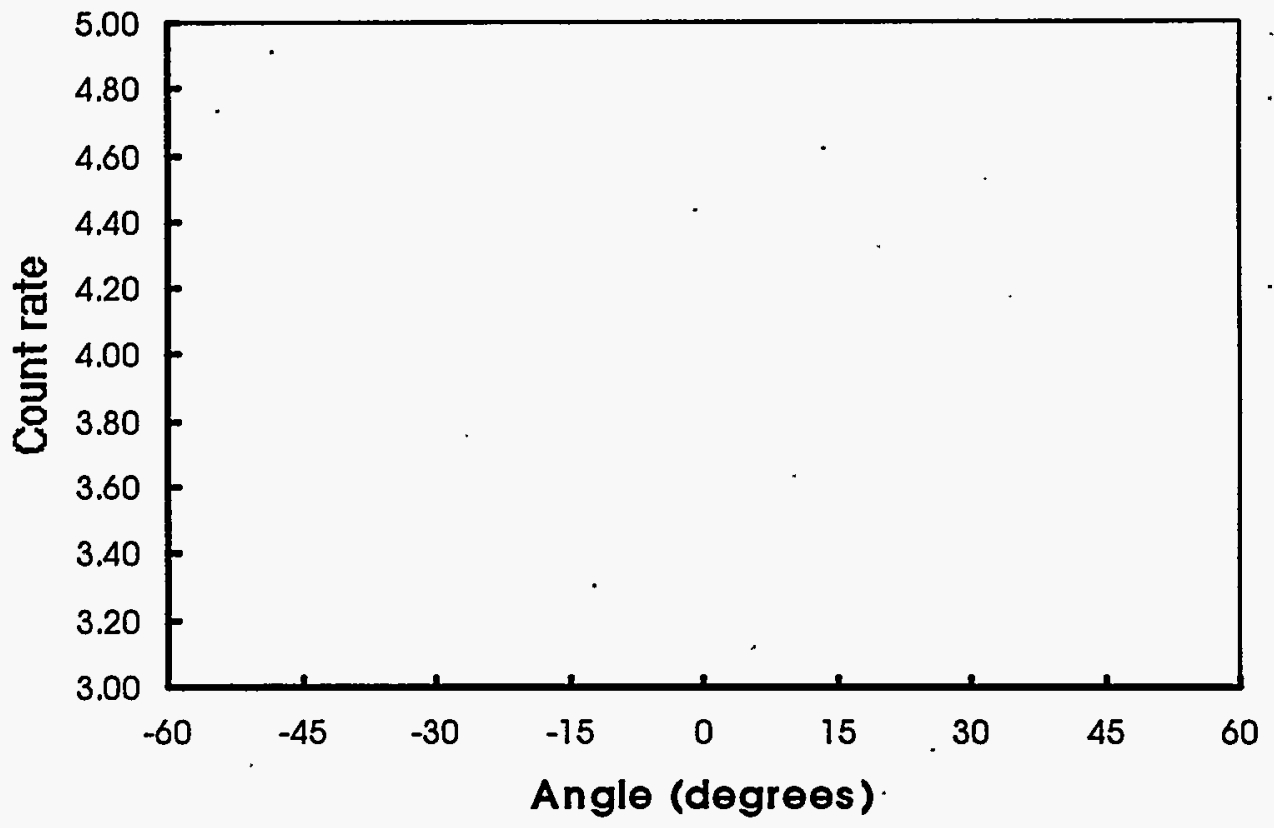

Figure 3.12. Measurement of Three EBRII Casks Located Inside the 2736-ZD Concrete Storage Vault Measured Using the Collimated Fast Neutron Detector Positioned at the Southeast side 



\subsection{Conclusions}

The NDA measurements satisfy the original objectives of verification of transuranic content and determination of the nontransuranic curie content of each cask. The plutonium content of 29 of the casks was verified, as demonstrated in Figure 3.1 in which the plutonium content calculated from the stated inventory value is linearly related to the measured neutron emission rate from the even plutonium isotopes. The remaining casks contain recycled plutonium or americium in which the neutron emissions from the plutonium are effectively masked by the much higher neutron emission rates from ${ }^{244} \mathrm{Cm}$. For these casks, the ${ }^{244} \mathrm{Cm}$ content was determined by neutron counting, and the plutonium content can be inferred by correlation with the ${ }^{244} \mathrm{Cm}$ content. It was also possible to relate the ${ }^{244} \mathrm{Cm}$ mass measured by neutron counting to the ${ }^{137} \mathrm{Cs}$ content, which is an estimate of burn up. This linear correlation is demonstrated in Figure 3.2, which provides an independent method of estimating the ${ }^{244} \mathrm{Cm}$ and hence the plutonium content of these remaining casks. Orie cask does not fit the linear correlations, as shown in Figure 3.2. This cask contained 12 americium target elements that were discharged from the reactor in 1970 . After correcting for decay, the mass of ${ }^{244} \mathrm{Cm}$ determined from neutron counting agrees within $10 \%$ of the declared ${ }^{244} \mathrm{Cm}$ mas calculated from the irradiation history. The plutonium and ${ }^{244} \mathrm{Cm}$ content declared on the inventory is in good agreement with the measured neutron emission rate. Thus, the plutonium content can be verified either by direct neutron counting for the low burn up mixed oxide, carbide, and nitride fuel elements or by correlation with the $244 \mathrm{Cm}$ content of the recycled plutonium or americium spent fuel elements.

Gamma emissions measured with intrinsic germanium detectors showed five radionuclides $\left({ }^{137} \mathrm{Cs}\right.$, ${ }^{134} \mathrm{Cs},{ }^{60} \mathrm{Co},{ }^{154} \mathrm{Eu}$, and ${ }^{208} \mathrm{Ti}$ ) were present in large enough amounts to be measured through the massive shielding in the casks. Table 3.2 lists the curie content of the gamma emitters that could be measured through the walls of the casks. The isotopic content of other radionuclides can be inferred from the measured ${ }^{137} \mathrm{Cs}$ content using ISOGEN or other burn up code that calculates radionuclide content as a function of fuel burn up. Table 3.3 lists the nontransuranic curie content of the casks based on ISOGEN calculations that relate the other radionuclides with the ${ }^{137} \mathrm{Cs}$ content measured by the intrinsic germanium detector. There are some discrepancies between the ${ }^{154} \mathrm{Eu}$ content measured for some of the casks and the ${ }^{154} \mathrm{Eu}$ content estimated from ISOGEN calculations. In most instances, accurate ${ }^{154} \mathrm{Eu}$ measurements were not possible because od the much greater ${ }^{137} \mathrm{Cs}$ activity. It is therefore recommended that the nontransuranic curie values given in Table 3.3 be used for inventory and waste disposal. 



\subsection{References}

Brackenbush, L. W., W. D. Reece and J.E. Tanner. 1984. Neutron Dosimetry at Commercial Nuclear Plants, Final Report of Subtask C: ${ }^{3}$ He Neutron Spectrometer. NUREG/CR-3610 (PNL4943), U.S. Nuclear Regulatory Commission, Washington, D.C.

Reilly, D., N. Ensslin, H. Smith, Jr. 1991. Passive Nondestructive Assay of Nuclear Materials. NUREG/CR-5550, U.S. Nuclear Regulatory Commission, Washington, D.C.

Schwartz, R. B., and C. M. Eisenhauer. 1982. Procedures for Calibrating Neutron Personnel Dosimeters. NBS Special Publication 633, U.S. Department of Commerce, Washington, D.C.

Stoddard, D. H. and H. E. Hootman. 1971. ${ }^{252}$ Cf Shielding Guide. DP-1246, Savannah River Laboratory, Aiken, South Carolina. 



\section{Distribution}

No. of

Copies

ONSITE

3 DOE Richland Operations Office

W. C. Johnson, Jr. A6-35

J. E. Trevino

P7-35

A. C. Walker

A6-35

3 Westinghouse Hanford Company

B. R. Fitzpatrick $\quad$ T4-40

D. A. Pratt

T4-03

D. R. Pyzel

T4-04
No. of

Copies

26 Pacific Northwest National Laboratory

G. K. Ackerman K6-44

M. J. Bagaglio P7-75

L. W. Brackenbush P7-03

S. W. Gority K6-44

D. L. Haggard (7) P7-03

J. F. Henderson P8-24

W. A. Hoober P8-24

J. D. Jensen P8-24

S. B. Johnston P8-24

G. L. Ketner P8-24

D. E. Knowlton P7-35

J. M. Seay P8-24

R. W. Stevens $\quad$ P8-24

PNNL Information Release (7) 
